\title{
Spinning Reserve from Pump Load: A Technical Findings Report to the California Department of Water Resources
}

November 2003

\author{
Prepared by \\ Brendan J. Kirby \\ John D. Kueck
}

Oak Ridge National Laboratory 


\section{DOCUMENT AVAILABILITY}

Reports produced after January 1, 1996, are generally available free via the U.S. Department of Energy (DOE) Information Bridge:

Web site: http://www.osti.gov/bridge

Reports produced before January 1, 1996, may be purchased by members of the public from the following source:

National Technical Information Service

5285 Port Royal Road

Springfield, VA 22161

Telephone: 703-605-6000 (1-800-553-6847)

TDD: 703-487-4639

Fax: 703-605-6900

E-mail: info@ ntis.fedworld.gov

Web site: http://www.ntis.gov/support/ordernowabout.htm

Reports are available to DOE employees, DOE contractors, Energy Technology Data Exchange (ETDE) representatives, and International Nuclear Information System (INIS) representatives from the following source:

Office of Scientific and Technical Information

P.O. Box 62

Oak Ridge, TN 37831

Telephone: 865-576-8401

Fax: 865-576-5728

E-mail: reports@adonis.osti.gov

Web site: $\mathrm{http}: / / w w w . o s t i . g o v / c o n t a c t . h t m l$

This report was prepared as an account of work sponsored by an agency of the United States Government. Neither the United States government nor any agency thereof, nor any of their employees, makes any warranty, express or implied, or assumes any legal liability or responsibility for the accuracy, completeness, or usefulness of any information, apparatus, product, or process disclosed, or represents that its use would not infringe privately owned rights. Reference herein to any specific commercial product, process, or service by trade name, trademark, manufacturer, or otherwise, does not necessarily constitute or imply its endorsement, recommendation, or favoring by the United States Government or any agency thereof. The views and opinions of authors expressed herein do not necessarily state or reflect those of the United States Government or any agency thereof. 
ORNL/TM-2003/99

\title{
Spinning Reserve from Pump Load: A Technical Findings Report to the California Department of Water Resources
}

\author{
Principal Authors \\ Brendan Kirby \\ John Kueck \\ Prepared for the \\ Transmission Reliability Program \\ Office of Electric Transmission and Distribution \\ U.S. Department of Energy \\ And the Energy System Integration Program \\ Public Interest Energy Research, California Energy Commission \\ Oak Ridge National Laboratory \\ November 2003 \\ CERTS—Load as a Resource \\ The work described in this report was coordinated by the Consortium for \\ Electric Reliability Technology Solutions (CERTS) and funded by the \\ Transmission Reliability Program, Office of Electric Transmission and \\ Distribution, of the U.S. Department of Energy, and by the California Energy \\ Commission, Public Interest Energy Research Program, under Work for \\ Others Contract No. BG 99-396 (00).
}

\author{
Prepared by \\ OAK RIDGE NATIONAL LABORATORY \\ Oak Ridge, Tennessee 37831-6070 \\ managed by \\ UT-BATTELLE, LLC \\ for the \\ U.S. DEPARTMENT OF ENERGY \\ under contract DE-AC05-00OR22725
}





\section{CONTENTS}

Page

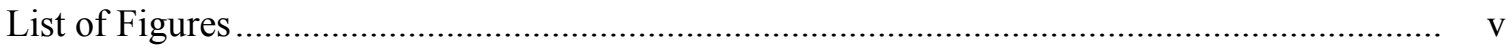

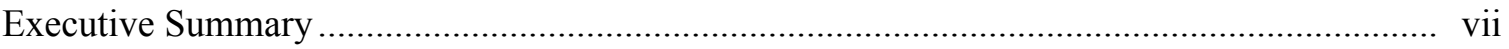

1. Concept of Spinning Reserve from Pump Load ............................................................... 1

2. Water Project Power Considerations .............................................................................. 3

3. CDWR Pumping System Operational Restrictions and Soft Start for

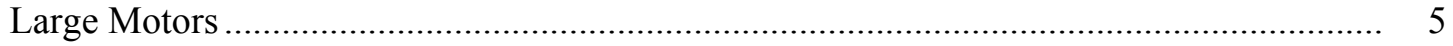

3.1 Operational Restrictions ................................................................................... 5

3.2 Restrictions Due to South Bay and Piped Systems...................................................... 6

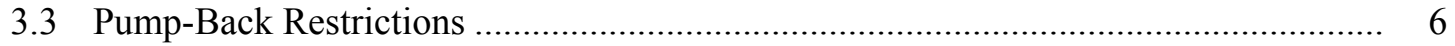

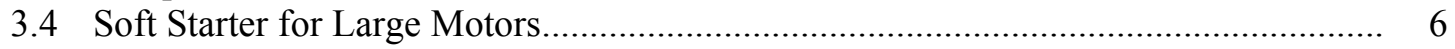

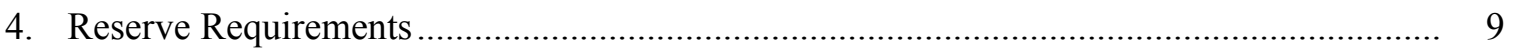

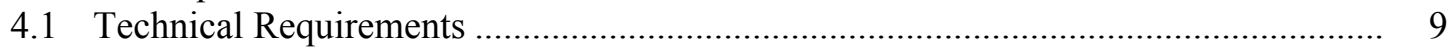

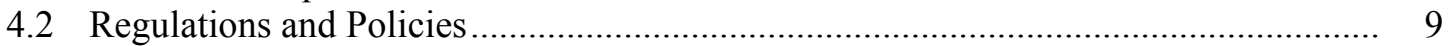

4.2.1 Federal Energy Regulatory Commission ...................................................... 10

4.2.2 North American Electric Reliability Council ............................................... 11

4.2.3 Western Electricity Coordinating Council .................................................. 12

4.2.4 California Independent System Operator ............................................... 12

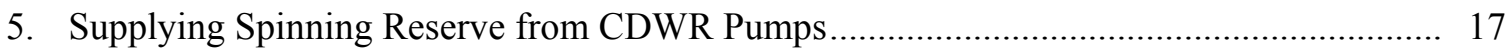

5.1 Modeling Contingency Reserve Supplied by CDWR Pumps.................................... 17

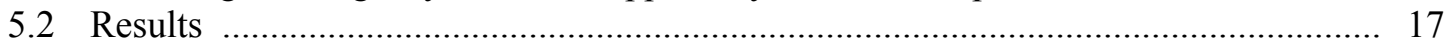

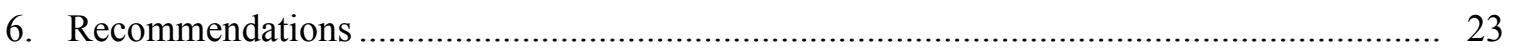

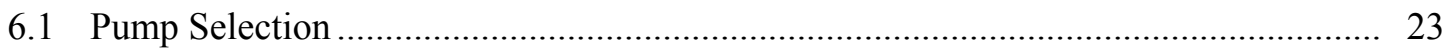

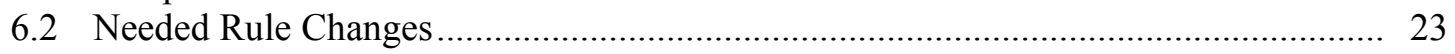

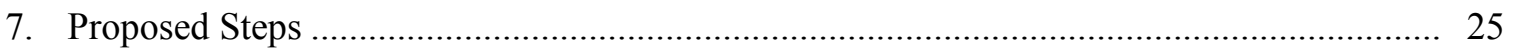

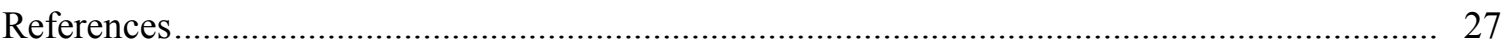

Appendix A

Siemens Technical Concept and Budgetary Estimate for Pump Motor Starting Frequency Converter

Appendix B

Spinning and Non-Spinning Revenue Per Pump.......................................................... 39

Appendix C

Notes from WECC MORC working group meeting of November 6, 2003 ........................ 45 



\section{LIST OF FIGURES}

Figure

Page

4.1 Governor response and contingency reserves successfully restored the generation/load balance after the loss of $2600 \mathrm{MW}$ of generation 10

4.2 Contingency reserves provide a coordinated response to a sudden loss of supply 10

4.3 Average hourly CAISO contingency reserve prices follow an expected daily pattern with spinning reserve, the fastest service, having the greatest value: $11 / 2001-10 / 2002$

4.4 The daily pattern of hourly CAISO contingency reserve prices for July of 2002 showed the same expected pattern, but those prices were considerably higher than the annual average hourly prices shown in Fig. 4.3

5.1 CDWR is a sophisticated power purchaser, minimizing costs by pumping during off-peak times whenever possible

5.2 Total annual revenue from selling spinning reserve could have been $\$ 12.9$ million in 2002 with 1999 water conditions

5.3 Non-spinning reserve revenue would have been only $\$ 5.6$ million for the same 2002 ancillary service prices and 1999 water conditions

5.4 Setting a minimum acceptable price for selling spinning or non-spinning reserve reduces revenue, but it also reduces the exposure to curtailment 



\section{EXECUTIVE SUMMARY}

The Oak Ridge National Laboratory (ORNL), at the request of the California Energy Commission and the U.S. Department of Energy, is investigating opportunities for electrical load to provide the ancillary service of spinning reserve to the electric grid. The load would provide this service by stopping for a short time when there is a contingency on the grid such as a transmission line or generator outage. There is a possibility that a significant portion of the California Independent System Operator's (CAISO's) spinning reserve requirement could be supplied from the California Department of Water Resources (CDWR) pumping load.

Spinning reserve has never been supplied from load before, and rule changes would be needed to allow it. In this report, we are presenting technical findings on the possibility of supplying spinning reserve from pumping system load. In parallel, we are pursuing the needed rule changes with the North American Electric Reliability Council (NERC), the Federal Energy Regulatory Commission (FERC), the Western Electricity Coordinating Council (WECC), and the CAISO. NERC and FERC have agreed that they have no prohibition against supplying spinning reserve from load. The WECC Minimum Operability Reliability Criteria working group has agreed that the concept should be considered, and they are presently discussing the needed tariff and rule changes.

Presently, spinning reserve is provided by generation that is actually spinning but is operating at low power levels and can be ramped up quickly to provide reserve power. In a sense, this is an inefficient and environmentally unfriendly way of providing reserves because it requires the generator to operate at a low power level that may be inefficient and may discharge more pollutants per $\mathrm{kW}$ than operating at rated power. It would be better if this generation capacity were in a position to bid into the energy market. Providing an additional supply of spinning reserve would tend to reduce prices for both reserves and the regular electric energy market.

The CAISO is presently in the process of redesigning its market rules for ancillary services. The time is right to pursue this opportunity to supply spinning reserve from load. It is our hope that the CDWR will endorse this recommendation. ORNL will then work with FERC, NERC, WECC, and the CAISO to obtain the needed rule changes. This project would provide the CDWR with another option in the complex process of obtaining its energy at the lowest possible cost, while at the same time providing more flexibility to the ISO and relief to the energy market. After this project is implemented in California, we hope that the practice spreads across the nation, allowing much more flexibility in energy markets and increasing the availability of reserve services. 



\section{CONCEPT OF SPINNING RESERVE FROM PUMPING LOAD}

The concept of providing spinning reserve from the pump load is novel, but it builds on and complements the California Department of Water Resources's (CDWR's) existing State Water Project (SWP) energy management programs. The SWP's large megawatt size, coupled with CDWR's extensive knowledge of the California energy markets and its own loads, places it in an ideal position to evaluate the use of pumping load as spinning reserve and to design and implement a test project if the evaluation indicates that doing so is warranted.

Because of the high cost of electric power and the large amounts of power that CDWR both generates and consumes, CDWR is a sophisticated player in the California energy and ancillary service markets.

For CDWR, water delivery is the first priority, and any plans or modifications must consider this. The efficiency and reliability of water delivery cannot be compromised. However, CDWR'S participation in the ancillary services market has provided an important revenue source in the past, and CDWR is always interested in exploring new ideas.

Spinning reserve has traditionally been supplied from generators. It can be thought of as providing insurance. The supplier is paid for having it available whether it is called for or not. It is only to be called in the event of a genuine system emergency, such as a lost transmission line or failed generator. It should only be called for infrequently, perhaps a few times per month. It should be restored to service rapidly (within 15 to 30 minutes) so that the power system is protected against the next contingency. Having the option to supply spinning reserve from load would provide flexibility in CDWR operations, provide another source of revenue, increase the reliability of California's electricity supply by increasing reserves, and decrease all customers' energy bills because reserve generation would be freed up to supply energy.

Spinning reserve could be supplied by load by simply turning off the load (e.g., a pump motor) when the reserve service is called for. North American Electric Reliability Council (NERC) rules have required that spinning reserve be supplied by generators in the past, but NERC recognizes that advances in communication and control technology now make it possible for load to supply spinning reserve. NERC has stated that it would be receptive to a waiver request. Oak Ridge National Laboratory (ORNL) would work with the Federal Energy Regulatory Commission (FERC), NERC, Western Electricity Coordinating Council (WECC), and California Independent System Operator (CAISO) to work out the needed rule changes. FERC, NERC WECC, and CAISO rules are discussed in detail in Sect. 4.

ORNL has examined how CDWR pumping loads could be used to sell spinning reserve into the CAISO spinning reserve market. CDWR hourly power consumption information has been compared with CAISO hourly spinning reserve prices to determine how often CDWR could have sold spinning reserve, how much spinning reserve CDWR could have sold, and how much revenue this would have generated.

The results of the analysis are quite encouraging. Based on the aggregated CDWR pumping load, it was found that the CDWR could theoretically supply more spin capacity than the CAISO needs for over 3000 hours per year. Thus, even if CDWR bid in only selected plants, the total capacity made available for contingency load drop could be significant. Based upon current market design, we expect that CDWR would be paid the market clearing price for spinning reserve whenever CDWR elected to stand ready to supply the reserves. There would be additional payments whenever the reserves were actually called upon to deploy. Total annual revenues of over $\$ 11$ million are possible. The results are discussed in detail in Sect. 2. 



\section{WATER PROJECT POWER CONSIDERATIONS}

CDWR operates the SWP, which includes 18 pumping plants, 3 pumping-generating plants, and 5 hydroelectric power generating plants. The generation from the SWP's hydropower plants and from a coal-fired power plant in Nevada owned by CDWR produces enough electricity in a normal year to supply about two-thirds of the power needed to serve the pumping load. In an average year, CDWR generates 5 billion kWh and uses 6 billion kWh of energy. CDWR generation does participate in the ancillary service markets (up and down regulation as well as contingency reserves) when the price makes it worthwhile. To the extent possible, CDWR generates on peak and pumps off peak. There is an exchange agreement with Southern California Edison (SCE) that recognizes the temporal variations in the value of electric power: CDWR receives more energy off peak than it exchanges with SCE during on-peak periods. Most of the required additional power comes from long-term contracts. The present power exchange contracts with SCE expire at the end of 2004. CDWR is planning now for new options.

There is a concern that the CAISO might not dispatch load-based contingency reserves (spinning and non-spinning) only to respond to contingencies (the sudden, unexpected loss of a generator or transmission line) or that it might not restore the reserves as quickly as NERC rules dictate (15 to 30 minutes). It will be important to develop contracts carefully so that spinning reserve is called for only in bona fide contingency situations and that it is restored to service quickly. Fortunately, those principles are in the best reliability interest of both the CAISO and CDWR This issue is discussed further in Sect. 6. 



\section{CDWR PUMPING SYSTEM OPERATIONAL RESTRICTIONS AND SOFT START FOR LARGE MOTORS}

\subsection{OPERATIONAL RESTRICTIONS}

CDWR-owned generation facilities greatly reduce the cost of water pumping. They minimize the amount of power that must be purchased. Generation is scheduled to optimize its value in the energy markets rather than to directly supply the pumping loads. There are a number of significant environmental concerns, including water quality and wildlife habitat, for which regulatory constraints are imposed on operations for both hydropower generation and water pumping.

\section{Pump Strings}

CDWR's pumping facilities are located along some 660 miles of aqueduct. The aqueduct is composed of river channels, reservoirs, canals, pipelines, and tunnels. There is little storage along much of the aqueduct, and in some locations, pumps operate as "strings" to keep the flow even. Turning one pump off at any plant to supply spinning reserve would cause a flow imbalance in the string, so pumps would have to be turned off and on at the same time at every plant. There may be sufficient storage, however, to accommodate the sale of spinning reserves ( $\sim 30$ minutes). Pumping is done primarily in off-peak hours, with as few strings on during on peak hours as possible.

Two pumping strings may present restrictions on the times that spinning reserve could be supplied. The first string is composed of the Buena Vista, Wheeler Ridge, Wind Gap, and Edmonston plants. Pumps may possibly be stopped individually on the string, but only for a maximum of 30 minutes. Dos Amigos, the water plant feeding into this string, and Pearblossom, one of the water plants on the output of the string, may be capable of independent interruption for 2 hours before water storage limits are reached. The second pumping string is Las Perillas and Badger Hill. It is possible that each of these pumps could be stopped individually for a period of only 30 minutes.

When a pumping string is called upon to supply spinning reserve, it is reasonable to assume that only the largest pump in each plant of the string will be stopped. The pump motor ratings for each of the pumping string plants are as follows:

\section{First String}

Buena Vista

Wheeler Ridge (Teerink)

Wind Gap (Chrisman)

Edmonston

$$
\begin{array}{lrll}
\text { Pumps 1-3: } & 8,500 \mathrm{hp} & \text { Pumps 4-10: } 17,000 \mathrm{hp} \\
\text { Pumps 1-3: } & 10,000 \mathrm{hp} & \text { Pumps 4-9: } 20,000 \\
\text { Pumps 1-3: } & 22,000 \mathrm{hp} & \text { Pumps 4-9: } \\
\text { Pumps 1-14: } & 80,000 \mathrm{hp} & \text { (These pumps provide a large lift.) }
\end{array}
$$

\section{Second String}

Las Perillas

Badger Hill

The pump motors, in general, are designed for multiple starts per day. A rule of thumb has been two starts with a 30-minute cooldown period between them, then a 1-hour cooldown. The large Edmonston pumps, $80,000 \mathrm{hp}$, use motor generator sets to assist in starting; these motors are not started across the line at rated voltage and frequency. The motor generator sets provide a form of soft start, where the motor is started at a reduced frequency. Soft starting is discussed further in Sect. 3.4. 


\subsection{RESTRICTIONS DUE TO SOUTH BAY AND PIPED SYSTEMS}

The South Bay aqueduct is operating at near rated capacity to satisfy demand in the South Bay area of San Francisco. This aqueduct was one of the first constructed, built in the early 1960s. It includes the South Bay and Del Valle pumping plants. These plants are sometimes operated at near full pumping capacity to satisfy demand, and spin would probably not be available during some months of the year.

In addition, some pumping plants are connected only by pipe, not by canal. An example is the Coastal Branch where the Badger Hill, Devil's Den, Bluestone, and Polonio Pass plants combine to pump water over an elevation of $2500 \mathrm{ft}$. Interrupting pumps may present hydraulic concerns during some loading conditions.

\subsection{PUMP-BACK RESTRICTIONS}

In some cases, CDWR will pump into reservoirs either to fill the reservoir for water supply during off-peak hours or simply to provide energy storage so that the pumps can be operated as generators during on-peak hours. These decisions are made on a daily basis using an avoided-cost analysis. Spinning reserve could be factored into the analysis. Typically, spinning reserves prices fluctuate with energy costs, but there have been times when spin prices have been high in the middle of the night in the California market. In these cases, there would be a significant opportunity for revenue, as well as an opportunity to reduce the high price for spinning reserve by providing it from other sources.

\subsection{SOFT STARTING FOR LARGE MOTORS}

Presently, the Teerink and Chrisman pump motors are started "across the line" but unloaded (pumps running in air instead of water). The motor and pump accelerate to synchronous speed in about 2 seconds. Considering that the rotational inertia of the pump and motor is about one million foot pounds, and that this inertia is accelerated to synchronous speed in 2 seconds, offers a sense of the forces involved with an across-the-line start.

A soft start is a reduced-voltage, reduced-frequency start. It starts the motor more slowly with reduced stress. A form of soft start is provided for the large Edmonston pump motors using the motor-generator set. This soft start is not used on the other pump motors at the other pumping plants. The motors at Teerink and Chrisman are rated at 10,000, 20,000, 22,000, and 44,000 hp. Although smaller than the motors at Edmonston, these are not small motors by any means, and they are subjected to large stresses when starting.

Large synchronous motors are typically equipped with damper (or amortisseur) windings used for starting. The damper winding performs the same function as the squirrel cage winding in the rotor of an induction motor. It is used to create torque when the rotor is slipping (running behind synchronous speed) during starting. A synchronous motor started across the line is started as an induction motor using the damper winding, and the field is switched on only when it is running near synchronous speed. Across-the-line starting results in high inrush current and stress on the circuit breaker and windings. A soft starter for a synchronous machine usually operates the machine as a synchronous machine at variable frequency. This means that the field is excited from zero speed, but the starting frequency is quite low and is raised gradually.

Although these motors have been designed to start at rated voltage and frequency, a tremendous amount of force is placed on the amortisseur winding when the motor is started. CDWR has had to rebuild and reblock amortisseur windings in Teerink and Chrisman pump motors in the past. The exact cost of motor degradation has been the subject of analysis and discussion, but this may be a location where we would want to consider a soft start. 
The soft-start method is summarized as follows.

Typically, a soft starter, or converter, is set up to start a number of motors at a plant. The soft starter is a variable-frequency drive that converts both frequency and voltage. Each motor has two circuit breakers feeding it, one on the soft starter output bus and one on the main power supply bus or line. To start a motor, it is connected to the soft starter, accelerated up to speed, synchronized to the line, and then switched over to the line. Reducing voltage means less torque is applied to the motor shaft; reducing frequency means that the motor accelerates more slowly. Once the motor is running and synchronized, the soft starter is available to start the next motor.

There are two basic synchronizing methods. In the first method, the motor is accelerated slowly with reduced magnetic flux (using reduced input voltage) to a speed a few percentage points above synchronous speed. The converter is then disconnected from the motor. As the motor coasts back down to synchronous speed, it is fully excited, and it is connected to the line supply at the instant the motor voltage and phase coincide with those of the line supply. This transition is monitored and controlled by a synchronizing device. In the second method, the frequency is raised slowly until the speed reaches $95 \%$ of the synchronous speed. The synchronizing device controls the speed setpoint until the synchronizing point is precisely reached. The converter is then disconnected, and the motor circuit breaker is closed. The amortisseur winding will not provide enough torque itself to accelerate both the motor and pump impeller, and the motor's field winding will also need to be controlled during starting.

Because the soft starter operates for only two or three minutes, it does not have to have the same power rating as the motor. About 10 to $20 \%$ of rated motor horsepower is probably a good estimate of the rating needed for a starter for a large synchronous motor driving a centrifugal pump. As an example, Siemens manufactures load-commutated inverters in sizes up to $100,000 \mathrm{hp}$. For a 44,000-hp motor, the largest motor at Chrisman, a starter rated at $9 \mathrm{MW}$ should be adequate. This is one of the standard sizes that Siemens manufactures.

Siemens has provided a budgetary estimate for a 9-MW starting frequency converter, which is attached as Appendix A. The estimate for a 9-MW load-commutated current source inverter includes the input circuit breaker and transformer, the starting frequency inverter, control units for the existing field excitation controller, the synchronzing unit, the output transformer, and 11 output circuit breakers that would be used to connect to each pump motor. The cost for the entire system would be around $\$ 1.5$ million for one pumping plant. The estimate was done for the Chrisman plant, and the same system could be used for the smaller motors at the Teerink plant. It may be advantageous to use identical equipment for both sites for spare parts and economy in design and manufacture. The total installed cost would probably be around $\$ 2.25$ million per plant. 



\section{RESERVE REQUIREMENTS}

The electric power system is unique in that aggregate production and consumption must be matched instantaneously and continuously. Several types of controllable reserves are maintained to help the system operator achieve this required generation/load balance. Regulating reserves compensate for the continuous random minute-to-minute fluctuations in load and uncontrolled generation. Frequency-responsive reserves compensate for the frequency deviations. The daily cycling of load is compensated through load following and generator dispatch. Finally, sudden failures of generation and transmission are addressed with three additional reserve products: spinning reserve, non-spinning reserve, and supplemental or replacement reserve (collectively referred to as "contingency reserves").

Conceptually the generation/load balance can be maintained by controlling generation, load, or both. Historically, system operators have tended to control generation almost exclusively. Generators are typically in the business of providing their services to the power system, so their business models (whether they are owned by an integrated utility or are independent) accommodate following system operator directives. Communication and control technology also has made it easier to monitor and control a few large resources than numerous smaller resources. Consequently, the rules governing how the power system is operated were developed at a time when large generators were essentially the only resources available to support system reliability. Rules were prescriptive as to the actions to be taken and the technologies to be used, rather than being results oriented (i.e., performance based).

Restructuring has changed the business relationships between generators and the system operator. Technology has advanced to allow loads to be responsive. Energy costs have risen and have become more volatile from hour to hour, providing incentives for loads to respond. Rules established by regulators and technical organizations are being changed to accommodate this new set of circumstances.

\subsection{TECHNICAL REQUIREMENTS}

While responsive load theoretically can provide almost any service the power system requires (black start may be the only exception), most loads are best suited to provide contingency reserves. Contingency reserves restore the generation/load balance after the sudden unexpected loss of a major generator or transmission line. Power system frequency drops suddenly when generation trips, as shown in Fig. 4.1. In these instances, there is no time for markets to react. In the case shown in Fig. 4.1, frequency-sensitive generator governors responded immediately to stop the frequency drop. Spinning and supplemental reserves successfully returned frequency to $60 \mathrm{~Hz}$ within 10 minutes. Power systems typically keep enough contingency reserves available to compensate for the worst credible event (contingency). This is typically the loss of the largest generator or the largest importing transmission facility. In Texas, the simultaneous loss of two nuclear plants is credible (as shown by the event recorded in Fig. 4.1), so the Electric Reliability Council of Texas requires over $2600 \mathrm{MW}$ of contingency reserves. Frequency-responsive, spinning, supplemental, and replacement reserves operate in a coordinated fashion, as shown in Fig. 4.2.

\subsection{REGULATIONS AND POLICIES}

Although the general concepts of system operations and reliability are well established, implementation details continue to evolve as the industry is restructured. FERC, NERC, WECC, and the CAISO all have rules and procedures that govern contingency reserve requirements. 


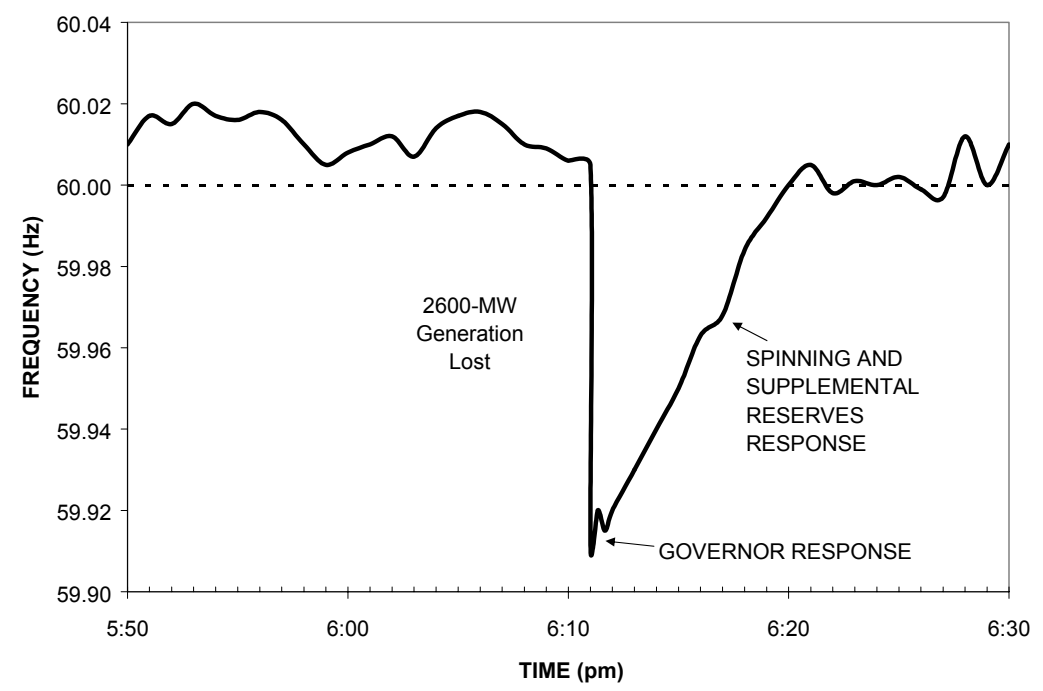

Fig. 4.1. Governor response and contingency reserves successfully restored the generation/load balance after the loss of $2600 \mathrm{MW}$ of generation.

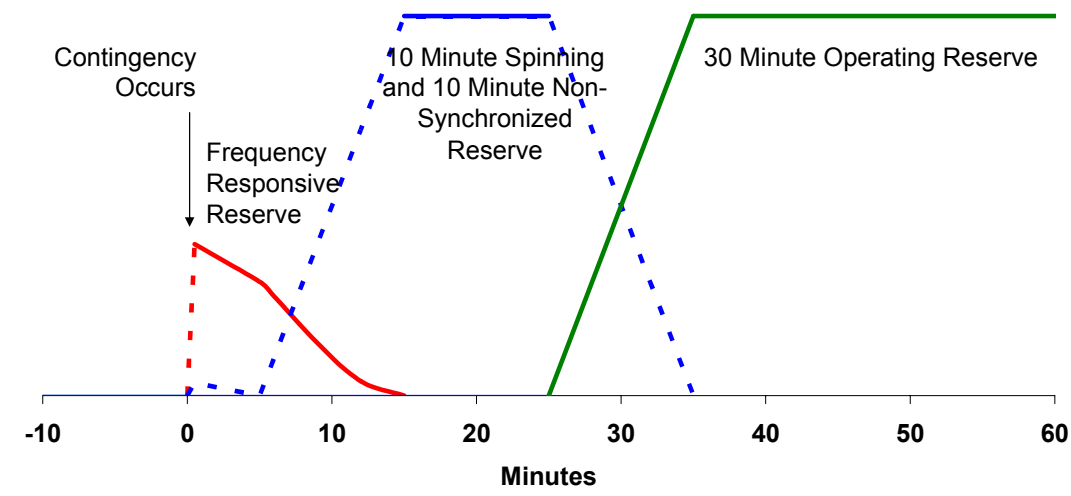

Fig. 4.2. Contingency reserves provide a coordinated response to a sudden loss of supply.

These rules, and even the specific service names, are not yet consistent among organizations; but the trend toward open, technology-neutral market-based solutions is clear.

\subsubsection{Federal Energy Regulatory Commission}

FERC, in its notice on Standard Market Design (SMD) (FERC 2002a), shows a clear preference for market-based solutions for energy supply and reliability. It also encourages demand participation on an equal footing with generation. The proposed SMD specifies dayahead markets for spinning and supplemental reserves but not for the 30-minute replacement reserve. These markets are to be integrated with the energy market. FERC also proposes operation of real-time markets for ancillary services. 


\subsubsection{North American Electricity Reliability Council}

In its most recent operating manual (NERC 2002), NERC has continued its move away from prescriptive requirements for operational practices to relying more on performance standards. Policy 1, Generation Control and Performance, specifies two standards that control areas must meet to maintain reliability in real time. ${ }^{1}$ The Control Performance Standard (CPS) covers normal operation, and the Disturbance Control Standard (DCS) deals with recovery from major generator or transmission outages.

Policy 1 still discusses the resources that control areas will need to meet the performance standards. Each control area is required to have sufficient operating reserves to "account for frequency support, errors in load forecasting, generation loss, transmission unavailability, and regulating requirements." It defines "sufficient operating reserves" as "the capacity required to meet the Control Performance Standard (Section A), Disturbance Control Standard (Section B), and Frequency Response Standard (Section C) of this Policy."2

NERC's DCS is a performance measure; it specifies that the control area must recover the generation/load balance within 15 minutes of the start of a contingency. To provide resources to meet the DCS, Policy 1 defines contingency reserves as a subset of operating reserves:

Each CONTROL AREA shall have access to and/or operate CONTINGENCY RESERVES to respond to DISTURBANCES. This CONTINGENCY RESERVE is that part of the OPERATING RESERVES that is available, following loss of resources by the CONTROL AREA, to meet the Disturbance Control Standard (DCS). CONTINGENCY RESERVE may be supplied from generation, controllable load resources, or coordinated adjustments to INTERCHANGE SCHEDULES. ${ }^{3}$

Policy 1 goes on to state that each regional reliability council will establish contingency reserve policies covering the minimum reserve requirements, the mix of spinning and supplemental reserves, and "the limitations, if any, upon the amount of interruptible load that may be included" (emphasis added). There is a further requirement that each control area or reserve sharing group carry at least enough contingency reserves to cover the most severe single contingency. NERC requires that reserves be restored within 90 minutes of deployment.

There are two important points here. First, the composition of the reserves is not specified. NERC no longer requires spinning reserves to come from generation (although regional councils are not prohibited from setting that requirement). ${ }^{4}$ Second, contingency reserves are to be used to meet the DCS standard. That is, they are to respond to contingencies. If they are used to respond to forecast errors, generation or transmission maintenance, or other such problems, they are not available to respond to contingencies. This latter distinction is important to responsive loads because it has a large impact on the response duration. Oddly, as we will discus in greater detail, responsive loads, unlike most generators, care about what the response is to be used for.

\footnotetext{
${ }^{1}$ Policy 1 contains five additional standards: Frequency Response and Bias, Time Control, Automatic Generation Control, Inadvertent Interchange, and Surveys.

${ }^{2}$ The frequency response standard will likely evolve into a performance standard similar to CPS and DCS, but it is currently still only a specification of how to set the frequency bias.

${ }^{3} \mathrm{NERC}$ capitalizes terms in its policies that have NERC-defined meanings.

${ }^{4}$ The "Terms and Definitions" in the NERC Operating Manual have not yet been updated, and spinning reserve is still defined as "unloaded generation that is synchronized and ready to serve additional demand."
} 


\subsubsection{Western Electricity Coordinating Council}

WECC specifies the minimum amounts of contingency reserve each control area in the West must carry (2002).

WECC sets the minimum contingency reserve requirement as the greater of (1) the largest contingency or (2) 5\% of the load served by hydroelectric resources, plus $7 \%$ of the load served by all other resources, with additions related to nonfirm energy imports and firm exports of reserves. WECC requires that at least $50 \%$ of contingency reserves be spinning, primarily to respond to frequency deviations.

These reserves are required to meet the DCS. WECC (2002) describes the DCS as follows: "Each control area or reserve sharing group shall include events that cause its Area Control Error (ACE) to change by at least $35 \%$ of the maximum loss of generation that would result from a single contingency." The recovery from DCS events must meet the following criterion: "Following the start of a disturbance, the ACE must return either to zero or to its pre-disturbance level within the time specified in the Disturbance Control Standard currently in effect in NERC Policy 1 [15 minutes]."

After responding to a contingency, the reserves must be restored in order to be prepared for the next contingency. WECC requires that reserves be restored within one hour: "After the occurrence of any event necessitating the use of operating reserve, that reserve shall be restored as promptly as practicable. The time taken to restore reserves shall not exceed 60 minutes" (WECC 2002).

WECC does not allow responsive load to provide spinning reserve; spinning reserve must come from generation. "Spinning Reserve-Unloaded generation which is synchronized and ready to serve additional demand. It consists of Regulating Reserve and Contingency Reserve" (WECC 2002). Responsive load, which can be interrupted within 10 minutes, is allowed to provide non-spinning reserve.

\subsubsection{California Independent System Operator}

The CAISO further refines the NERC and WSCC reserve requirements and operates dayahead and hour-ahead markets to obtain these reserves hourly. The CAISO specifies three contingency reserves:

Spinning Reserve: Reserve capability available within 10 minutes from on-line generating capacity.

Non-Spinning Reserve: Reserve capability available within 10 minutes from

- Off-line generation capacity

- Interruptible load and/or exports

- On-demand imports

- Excess spinning reserve

Replacement Reserve: Reserve capability available within 60 minutes from on-line or offline generating capacity.

The CAISO echoes the WECC requirements for the amount of reserves and the percentage that must be spinning. Replacement reserves are procured to meet the difference between the scheduling coordinator's scheduled load and the ISO-forecast load. 
The CAISO required 865 MW of spinning and non-spinning reserves in 2002, on average. The hourly peak requirement was $1376 \mathrm{MW}$ for each service, and the hourly minimum requirement was $585 \mathrm{MW}$. Markets are run for spinning reserve, non-spinning reserve, and replacement reserve. ${ }^{5}$ The CAISO ancillary service markets are locational, and prices diverge when there is transmission congestion. Annual average prices for the three contingency reserves are shown in Fig. 4.3. These prices show the expected daily pattern where prices are low at night and high in the afternoon. Also, spinning reserve, the highest-quality service, is 2.5 times as expensive, on average, as non-spinning reserve. Figure 4.4 shows the same pattern for July, when prices were considerably higher.

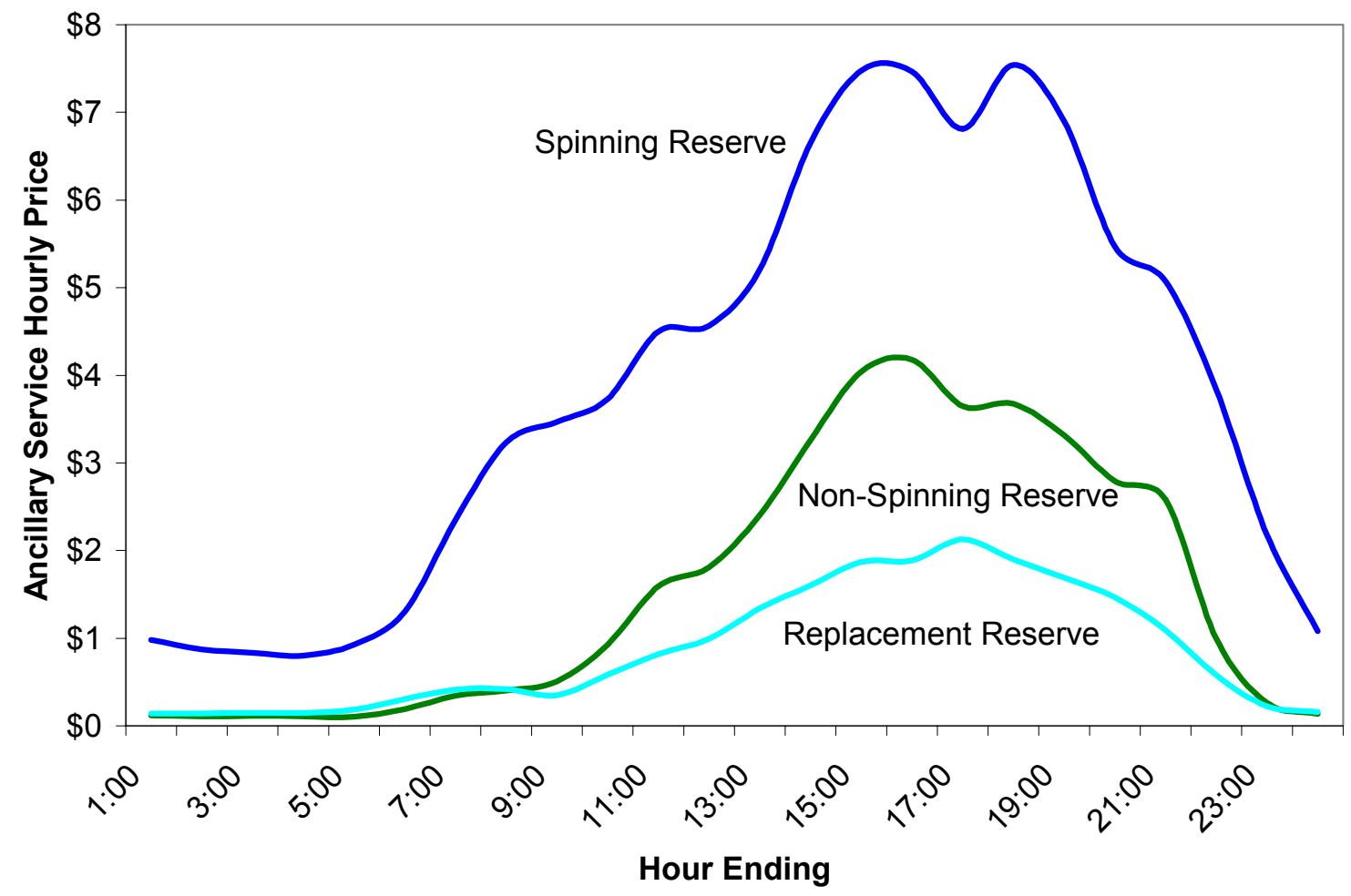

Fig. 4.3. Average hourly CAISO contingency reserve prices follow an expected daily pattern with spinning reserve, the fastest service, having the greatest value: 11/2001-10/2002.

\section{Spinning Reserve Capacity and Energy Bid Components}

Bids to supply spinning and non-spinning reserves to the CAISO have two parts: capacity and energy. Only the capacity bids are shown in Figs. 4.3 and 4.4. Bids are submitted for each hour that the supplier wishes to sell reserves to the system. The market clears based upon the capacity bid prices. All successful suppliers are paid the hourly capacity price for standing ready to supply reserves if they are needed. The energy bids are used only if reserves are actually deployed. In that case, reserves are selected for actual deployment based upon their energy bids, with the cheapest reserves being deployed more frequently. Each supplier is paid its energy bid price when it is utilized. Capacity and energy bids should be based upon their respective expected costs (CAISO 2003c).

\footnotetext{
${ }^{5}$ The CAISO runs separate markets for generation and load for non-spinning reserve and replacement reserve, although the prices are the same. The CAISO also runs markets for regulation up and regulation down.
} 


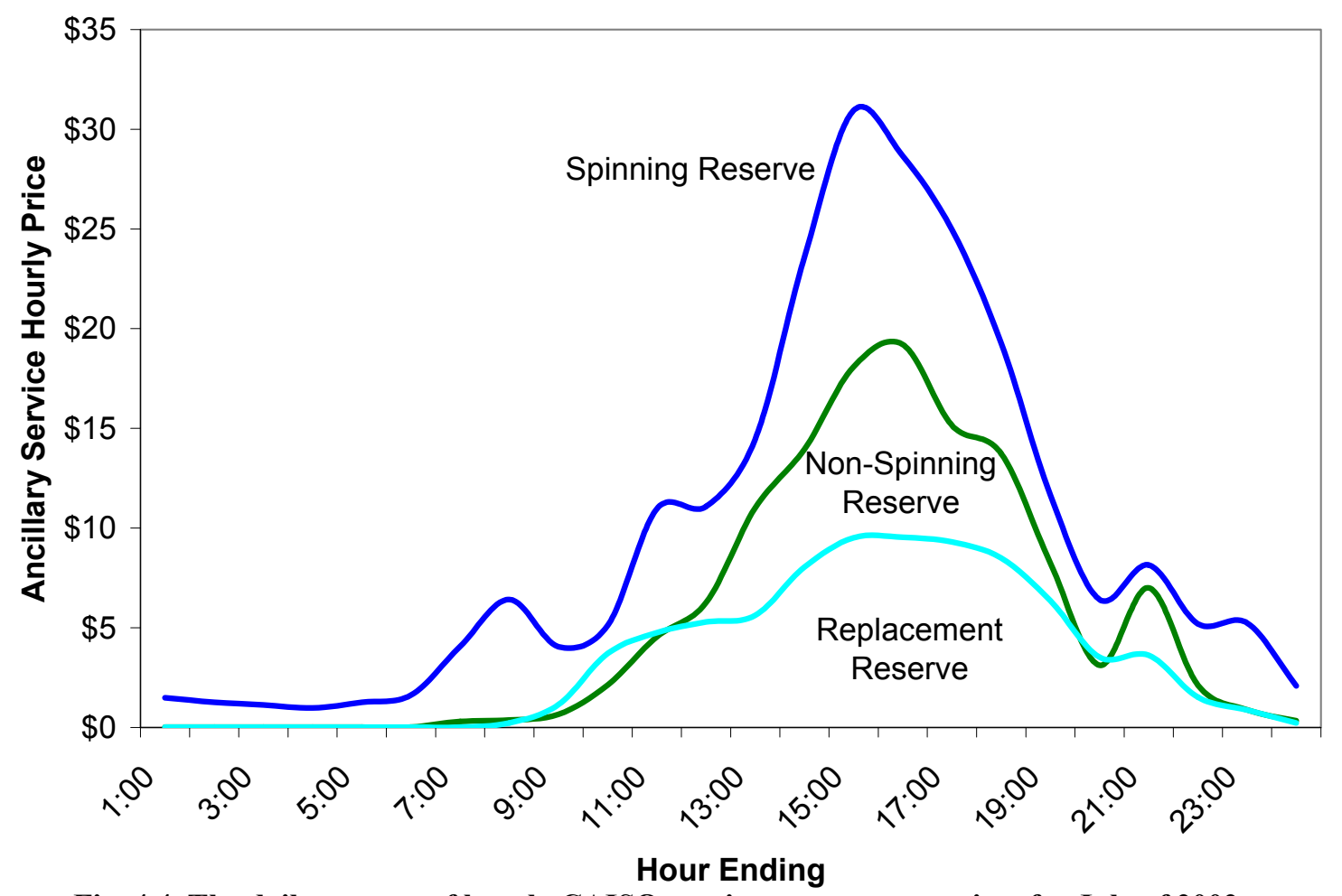

Fig. 4.4. The daily pattern of hourly CAISO contingency reserve prices for July of 2002 showed the same expected pattern, but those prices were considerably higher than the annual average hourly prices shown in Fig. 4.3

\section{Grid Management Charge}

The CAISO obtains the funds required for its operation from the grid management charge (GMC). There are three parts to this charge: one for recovering the ISO cost of providing control area services, a second for providing congestion management and transmission access services, and the third for recovering the cost of providing a market for the real-time energy and ancillary service transactions. This third GMC "market participation" charge applies to every purchase or sale of real-time balancing energy or ancillary service through the CAISO market. Both suppliers and loads pay this GMC charge on each megawatt-hour of ancillary service reserve that clears through the CAISO ancillary service market (CAISO 2000, CAISO 2003b, and Hoffman 2003).

This portion of the GMC charge was $\$ 0.975 / \mathrm{MWh}$ in 2002 (and is $\$ 1.30 / \mathrm{MWh}$ in 2003). Since both buyers and sellers are charged, this represented a $\$ 1.95 / \mathrm{MWh}$ surcharge on spinning and non-spinning reserves for 2002. The price of spinning reserve averaged $\$ 3.89 / \mathrm{MWh}$ and the price for non-spinning reserve averaged $\$ 1.57 / \mathrm{MWh}$ in 2002. Hence the GMC charge is a dominant consideration. The market clearing price for spinning reserve was below the GMC $(\$ 0.975 / \mathrm{MWh})$ for 4037 hours in 2002 . The market clearing price for non-spinning reserve was below the GMC for 6166 hours in 2002. It is not clear why generators were willing to sell reserves during these hours, since they were losing money. The GMC does not apply to selfprovision of ancillary services. Consequently, self-provision of reserves has increased in importance. About half of the reserves are self-provided. The CAISO is working on market redesign for 2004. It is hoped that the GMC for ancillary services will be addressed at that time.

There are two significant GMC consequences for CDWR provision of spinning reserve from its load. First, use of CDWR responsive load may be an attractive way for CDWR to meet its own spinning reserve obligation. The reserve value would then be the sum of the GMC and the market 
clearing price. Second, CDWR might wish to enter into arrangements with other load-serving entities to provide their spinning reserve requirements, thus allowing them to avoid the GMC. We did not analyze these opportunities further. We hope the GMC will be redesigned so that it does not influence the reserve markets, as is the CAISO's stated intent.

\section{CAISO Market Redesign}

The CAISO is actively redesigning the ancillary service markets. Some redesign will be implemented in the fall of 2003; more extensive redesign is expected in 2004. Redesign details are not yet available, and an analysis of proposed changes is beyond the scope of this report. The important point is that new CAISO market rules need to be evaluated as they are implemented to determine their impact on CDWR. Also, CDWR should actively participate in CAISO market redesign to ensure that the new market rules accommodate CDWR needs and capabilities. 



\section{SUPPLYING SPINNING RESERVE FROM CDWR PUMPS}

We modeled interactions between the CAISO spinning and non-spinning reserve markets and the CDWR pumping loads to determine how much reserve capacity could be supplied by CDWR pumps and what the value would be. This preliminary modeling may not have captured all of the limitations associated with each pumping station. The use of time-domain modeling ensures that these limitations can be easily identified and included in subsequent analyses.

\subsection{MODELING CONTINGENCY RESERVE SUPPLIED BY CDWR PUMPS}

We developed a Fortran-based, time series computer model to help evaluate the viability of using CDWR large pumps to supply contingency reserves to the California ISO power system. It utilizes hourly pumping loads at each pumping station. It combines these with hourly spinning and non-spinning reserve requirements and prices to determine the hourly revenue for each pumping station. The model is built to use locational reserve prices specific to each pumping station location. Limited resources prevented obtaining locational prices for this preliminary study. NP15 prices were used for all locations.

A minimum acceptable price can be specified for each pumping station. Reserves are not sold, and the pumping station does not incur the risk of having to curtail operation, unless the hourly reserve price exceeds this established minimum.

The model determines, for each hour and each pumping station, how much spinning and nonspinning reserve is available, how much reserve is sold, and how much revenue is generated. Results are summarized, providing total revenue per pumping station. Detailed information is also available concerning exactly when, and under what conditions, supplying reserves is most attractive.

The model can be run for any length of time. For this study, a full year was modeled. Hourly CDWR load data were obtained for each pumping station for 1999 from CDWR. Ancillary service price data were obtained for 2002 from the CAISO OASIS web site (CAISO 2003a). Disparate years were used because it was felt that 1999 was a more typical water year, while 2002 provided more ancillary services prices that were not distorted by dysfunctional markets. Unfortunately, the California power markets were not well-behaved until various market reforms were introduced in 2000 and 2001. The power markets settled down in the late summer of 2001 and appear to have been performing well since.

\subsection{RESULTS}

For the CDWR, water delivery is its first priority, and any plans or modifications must carefully consider this priority. The efficiency and reliability of the water delivery cannot be compromised. However, to the extent possible, CDWR pumps during off-peak hours to reduce pumping costs, as shown in Fig. 5.1.

Optimizing power purchases to minimize energy costs would appear to limit opportunities for selling contingency reserves. Contingency reserve prices tend to track energy prices and are highest in the middle of the day, as was shown in Figs. 4.3 and 4.4. Still, modeling the hourly CDWR load and CAISO ancillary service prices shows that there are significant opportunities. The modeling reveals that CDWR could have made $\$ 12.9$ million selling spinning reserve in 2002 (with 1999 water conditions). (This calculation was made using the actual price for spinning reserve and the number of megawatts the CDWR was using for pumping by the hour.) Nonspinning reserve would have yielded only $\$ 5.6$ million. Figure 5.2 shows the hourly revenue by month for spinning reserve; Fig. 5.3 shows the reduced revenue available from non-spinning reserve. 


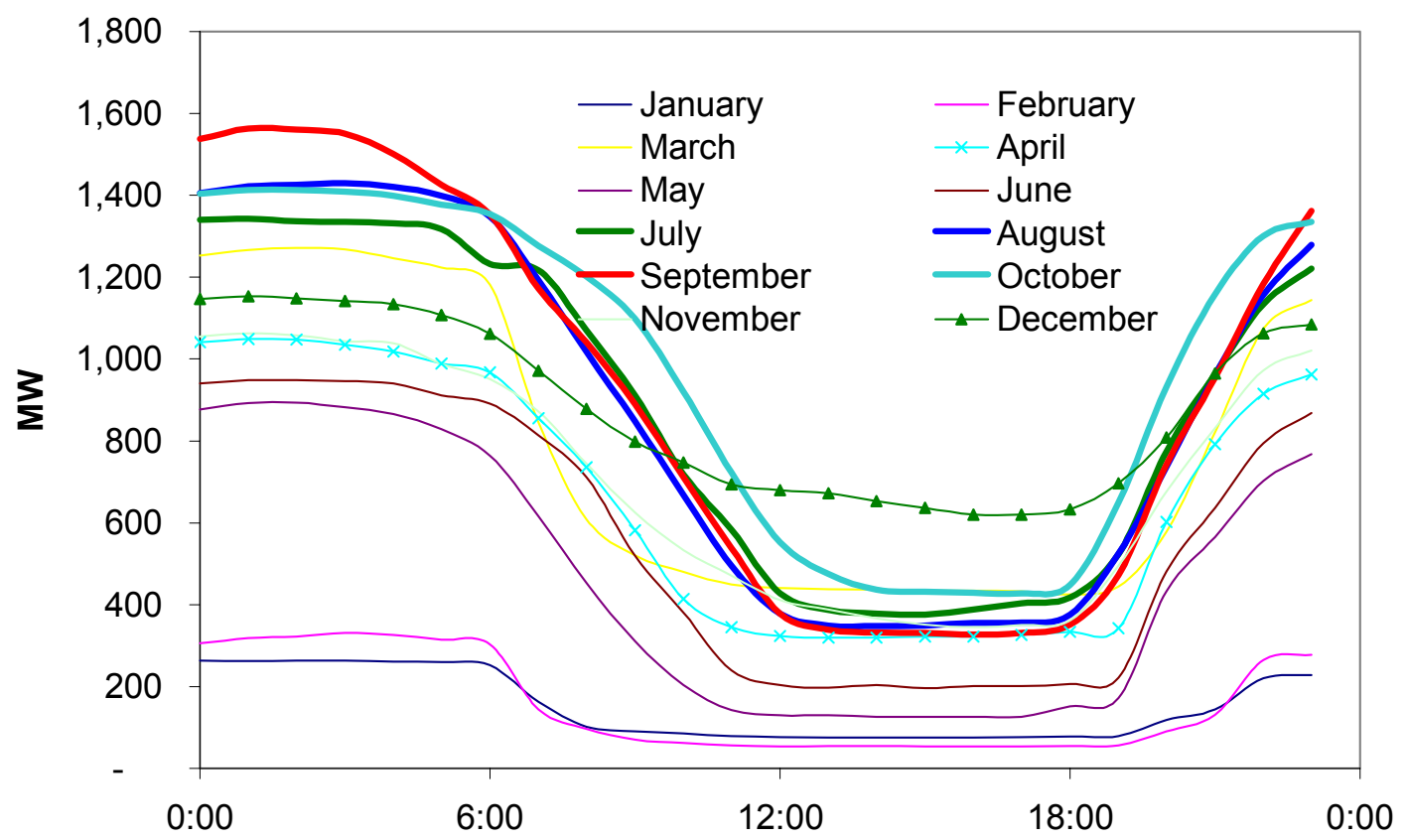

Fig. 5.1. CDWR is a sophisticated power purchaser, minimizing costs by pumping during off-peak times whenever possible.

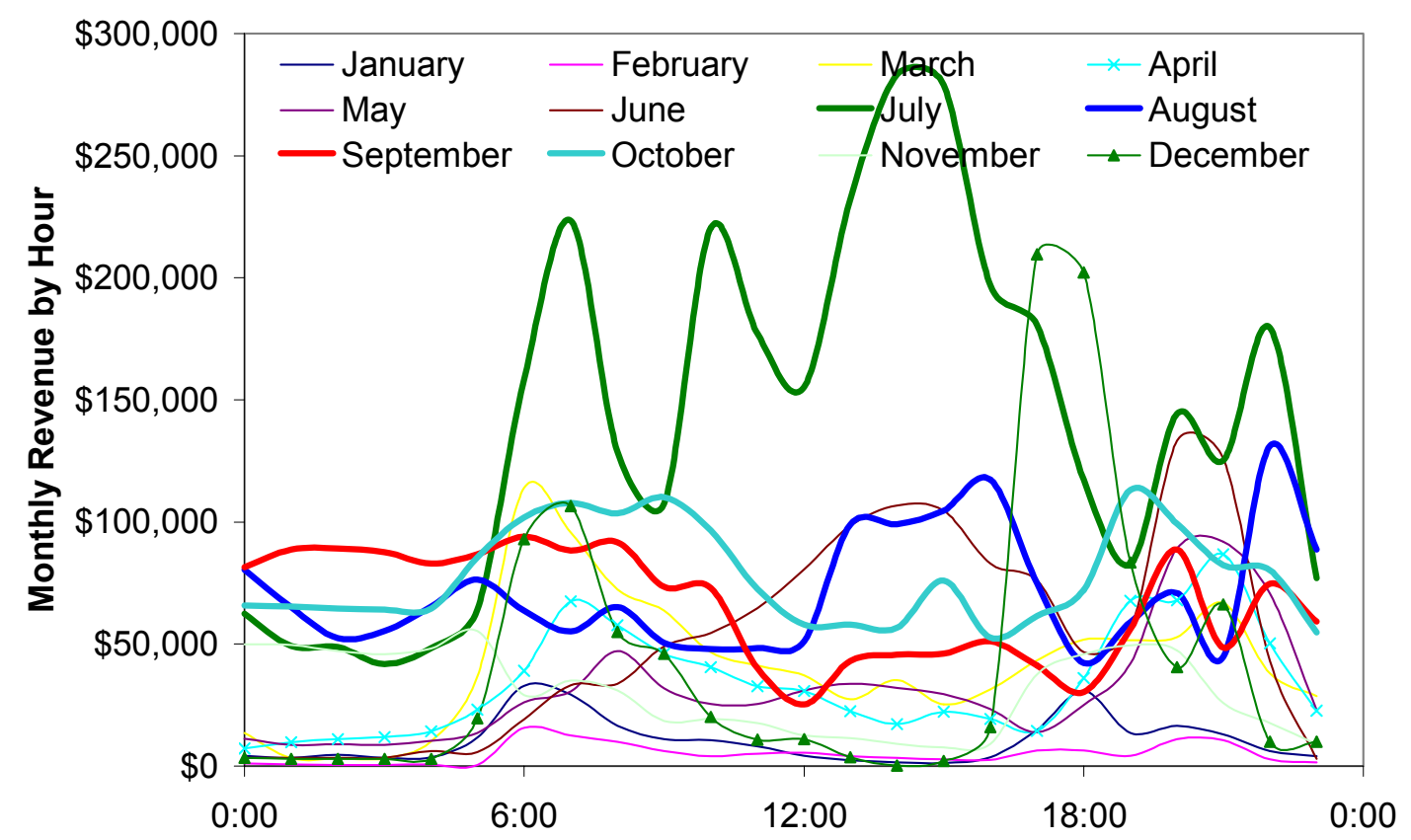

Fig. 5.2. Total annual revenue from selling spinning reserve could have been $\$ 12.9$ million in 2002 with 1999 water conditions. 


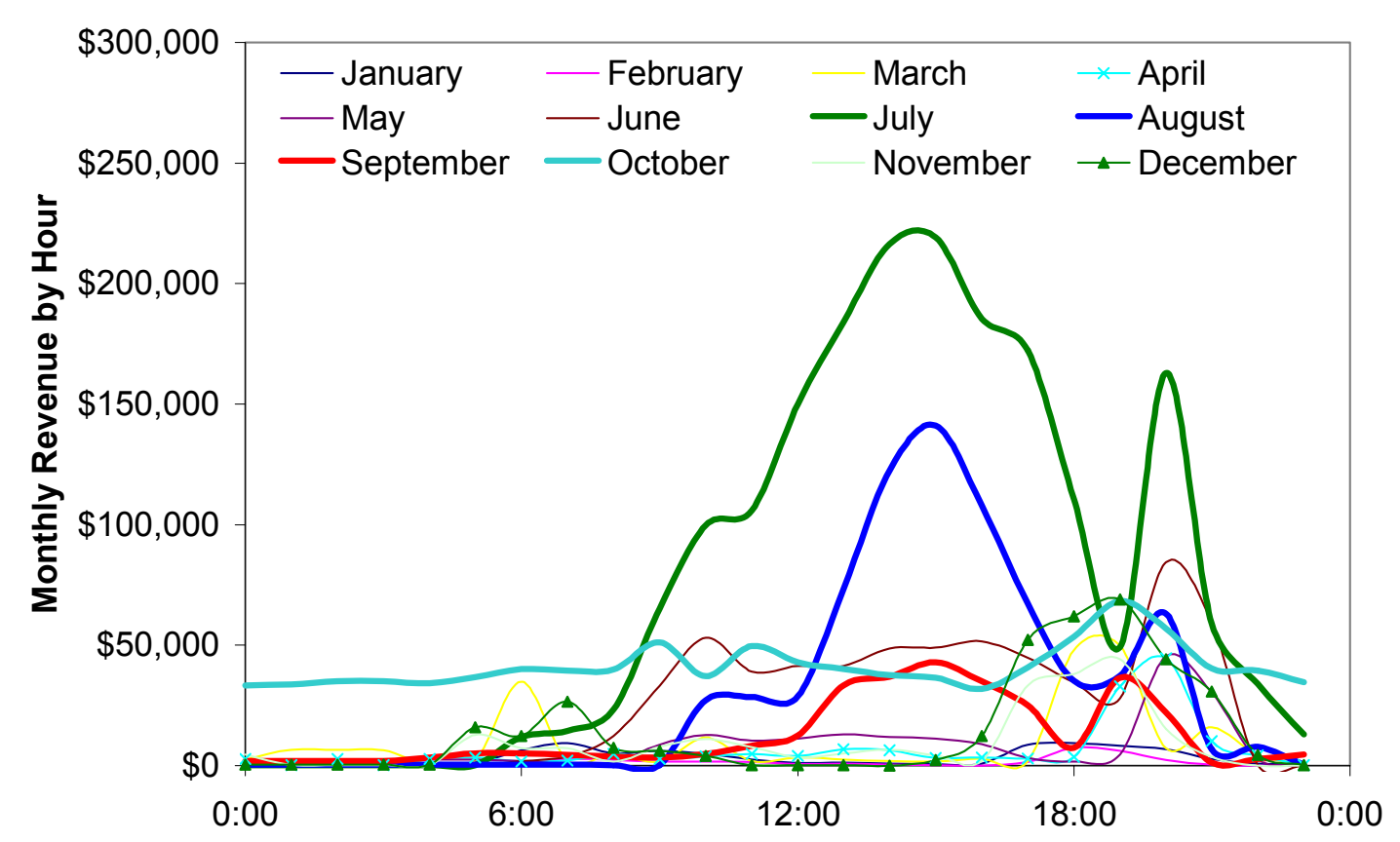

Fig. 5.3. Non-spinning reserve revenue would have been only $\$ 5.6$ million for the same 2002 ancillary service prices and 1999 water conditions.

Spinning reserve that could be supplied from CDWR pumps represents not only significant potential revenue but also a significant amount of the total California spinning reserve requirement. In fact, CDWR has sufficient potentially responsive load to supply $62 \%$ of the CAISO spinning reserve requirements under the conditions modeled. CDWR pumps had sufficient hourly capacity in operation to supply $100 \%$ of the spinning reserve requirements for 3292 hours in 2002.

\section{Minimum Price}

At times, the contingency reserve prices are quite low. CDWR might not want to expose its pumps to the risk of being curtailed unless it were receiving enough compensation to justify the risk. Determining what minimum price is acceptable requires assessing the probability of actually being called on to respond and the costs CDWR will incur to respond. That analysis is beyond the scope of this study. We did, however, calculate both the revenue reduction and the reduction in the number of hours for which CDWR would be exposed to curtailment risk as it raised the minimum acceptable price for both spinning and non-spinning reserves. Figure 5.4 shows that both the revenue and exposure hours drop as the minimum price rises, but that the exposure hours drop faster than revenue. Raising the minimum acceptable spinning reserve price from $\$ 1 / \mathrm{MWh}$ to $\$ 3 / \mathrm{MWh}$, for example, drops revenue by $13 \%$ (from $\$ 12.8$ million to $\$ 11.2$ million), but it drops the curtailment exposure by $32 \%$ (from 4718 hours to 3218 hours). It is likely that optimized minimum acceptable reserve prices will vary from plant to plant, from pump to pump, and from time to time, depending on the varying operating conditions. 


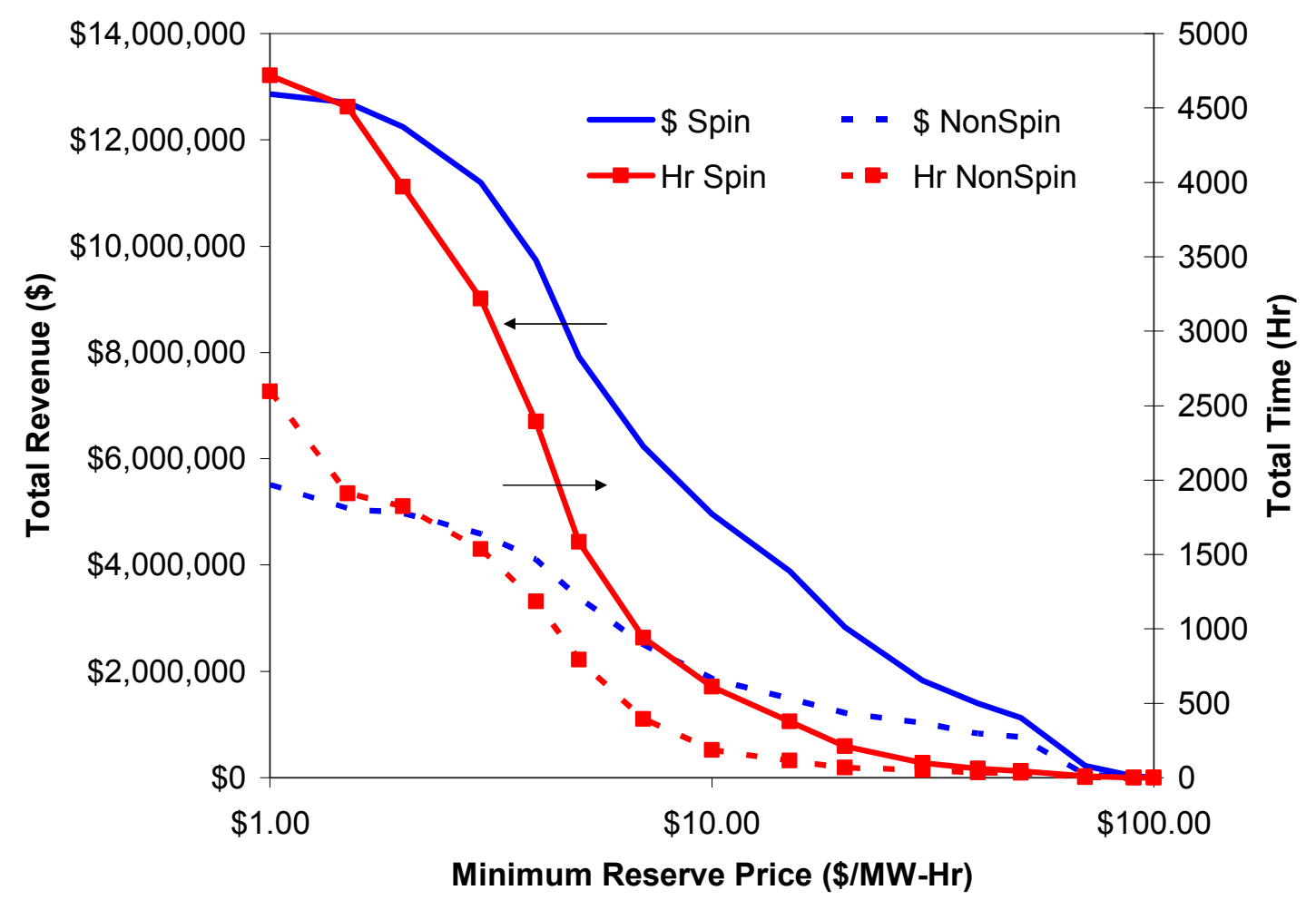

Fig. 5.4. Setting a minimum acceptable price for selling spinning or non-spinning reserve reduces revenue, but it also reduces the exposure to curtailment.

\section{Revenue from Individual Pumps}

The results presented so far are for the aggregated CDWR pumping load. That aggregated load is, of course, composed of individual pumping stations and individual pumps. CDWR supplied hourly loads for each pumping station, making it possible to evaluate individual stations and determine which ones offer the greatest potential benefit. CDWR did not supply hourly loads on each pump, but we synthesized individual pump loads by assuming a loading order for the pumps within each pumping station. This analysis was designed to determine how much revenue each individual pumping station and each individual pump could generate if that station and pump had response capability. This helps identify which pumps are potentially the best candidates for initial testing.

We modeled provision of both spinning and non-spinning reserve. We then sorted the individual pump revenues by total revenue for the year and by revenue per megawatt of pump size. This identified both the pumps that can generate the greatest revenue and pumps that can generate the greatest revenue normalized for pump size. These results are tabulated and presented in Appendix B.

Tables B.1 and B.2 (Appendix B) show the greatest revenue is available (for the conditions modeled) from the large Edmonston pumps (80,000 hp); Edmonston has four of the five pumps with the largest revenue potential for both spinning reserve and non-spinning reserve. When the evaluation is performed based upon revenue per megawatt of pump size, the smaller South Bay pumps (1300-2500 hp) are three of the five highest revenue producers. The Edmonston pumps are 26th and 33rd in the spinning and non-spinning reserve stacks on the basis of pump capacity in megawatts. 


\section{Spinning Reserve Capacity and Energy Bid Components}

Bids to supply spinning and non-spinning reserves to the CAISO have two parts: capacity and energy. Bids are submitted for each hour that the supplier wishes to sell reserves to the system. The market clears based upon the capacity bid prices. All successful suppliers are paid the hourly capacity price for standing ready to supply reserves if they are needed. The energy bids are only used if reserves are actually deployed. In that case, reserves are selected for actual deployment based upon their energy bids, with the cheapest reserves being deployed more frequently. Capacity and energy bids should be based upon their respective expected cost.

The capacity bid should be based upon the expected incremental cost to supply spinning reserve each hour from each pumping facility. These costs will include the cost of any change in operations that is necessary to be ready to respond - for example, operating with a more flexible, faster-responding, but less efficient pumping configuration. Bids are likely to vary from location to location and from hour to hour as operating conditions vary. Capacity bid costs are likely to be fairly low.

Revenue from selling contingency reserves needs to be high enough to cover any capital costs incurred in order to develop the capacity to supply the contingency reserves. The hourly capacity bids should not, however, include these costs since they are sunk costs. It is to be hoped that the market clearing prices (the actual prices received) for the contingency reserves will be high enough to recover the capital costs and turn a profit.

The energy bid should be based upon at least three factors: the cost of energy required to replace the energy being supplied in the reserve deployment, costs associated with disrupted operations, and the CAISO's GMC. The first and third are relatively easy to estimate. The second is more difficult.

First, when the load curtails operation in response to a contingency reserve deployment command from the system operator, the generator that had been supplying the load continues to operate. The load pays for the energy that it did not receive and that went to the system. The energy bid needs to recover the cost of this energy. But recovering the cost of the energy that the load did not consume is not enough. The load still has to accomplish the work (pump the water) that it had intended to accomplish with the energy it just gave to the system. Since energy operations were already optimized to minimize costs, it is likely that the replacement energy will be more expensive, perhaps requiring more on-peak purchases.

Second, there may be some additional costs associated with responding to the reserve deployment. Any operational cost could be minimized by making the response part of the standard set of services that the CDWR provides to the ISO. There will naturally be costs involved in any programming changes that are needed for the pump supervisory control and data acquisition (SCADA) system, and perhaps for certifying the pumps as official spinning reserve providers; but these should be one-time costs and should not be significant. Because the pumps should be called upon only two or three times per month, motor degradation from more frequent starts should be minimal. Larger motors could be supplied with soft starters, as described in Sect. 3.4.

Finally, the CAISO finances its operations through the GMC. A portion of the GMC is assessed on each megawatt hour of energy. In 2003, this charge is $\$ 1.30 / \mathrm{MWh}$. It needs to be added to the energy portion of the contingency reserve bid. 



\section{RECOMMENDATIONS}

\subsection{PUMP SELECTION}

Table B.1 (Appendix B) indicates that significant revenue is available from the string of Buena Vista, Wheeler Ridge (Teerink), Wind Gap (Chrisman), and Edmonston. However, these pumps probably could not be stopped individually for 2 hours because there is not enough water storage in the aqueduct pools between the pumps in string. If the CAISO agrees to a 30-minute interruption for spinning reserve, then some of the pumps could possibly supply it individually, because they could potentially be stopped individually for up to 30 minutes. If the CAISO requires spinning reserve to be supplied for 2 hours, then one pump in each plant in the entire string would be stopped to supply the service. The CDWR would make the decision as to whether the 2-hour interruption was possible.

As a second option, spin could be supplied from Las Perillas and Badger Hill string. Also, the revenue available per megawatt is quite attractive for the pumps at South Bay, Polonia Pass, Devil's Den, Bluestone, Barker Slough, Badger Hill, and many others. These may be attractive for a pilot program. As mentioned earlier, the South Bay aqueduct is operating at near rated capacity, and spin probably would not be available during some months of the year. In addition, the Badger Hill, Devil's Den, Bluestone, and Polonio Pass plants combine to pump water over a substantial elevation, so interrupting pumps might present hydraulic concerns. Again, it may be possible to stop one pump in each plant in the string. This decision would be made by the CDWR after analysis. This decision will be a factor of whether the duration of the pump outage is 30 minutes or 2 hours. The duration will be decided in the upcoming CAISO ancillary services market redesign.

\subsection{NEEDED RULE CHANGES}

Now that the CAISO is actively redesigning the ancillary service markets, it is appropriate to approach WECC and request a waiver to supply spinning reserve from load and to allow it to be supplied for a period of 30 minutes. After we have obtained WECC approval, the request could be made to the CAISO to include this change in the redesign. Even if the CAISO is not able to make the change from 2 hours to 30 minutes, we believe that it would be amenable to allowing spinning reserve to be supplied by load.

The 2-hour sustained off-time requirement may be difficult to meet. It will limit the locations at which and times during which the CDWR is able to respond. It may be in the CAISO's interest to reduce the 2-hour requirement to make spinning reserve much easier to supply from load.

We are now entering the formal process to request from the CAISO and WECC the capability to supply spinning reserve from load, and request that this service be supplied for a time frame of 30 minutes. This request could be considered during the redesign of the ancillary services market. The steps toward making the change are listed in Section 7. 
One argument for a shorter deployment time is that replacement reserves are required to be on within 1 hour, so they should replace the spinning and non-spinning reserves. Another possibility is that CDWR might offer to be able to redeploy in the unlikely event that another contingency occurs within the 2 hours. It might be possible to shut down the high-value-permegawatt pumps that are not located in the strings for 2 hours. 


\section{STEPS TOWARD THE RULE CHANGE}

The following are the planned steps to achieve the rule change.

- ORNL has confirmed with FERC that the existing rule for spinning reserve allows the service to be provided by shedding load. In fact, the proposed SMD stated that load that meets the independent transmission provider standards for generator performance could be used for spinning reserve. In addition, FERC specifies no time limits for the provision of spinning reserve; the time limit is to be determined by the local independent transmission operator.

- We have also confirmed that NERC has no prohibition against supplying spinning reserve by shedding load.

- ORNL has made a presentation to the WECC Minimum Operating Reliability Committee (MORC) working group on the concept. The working group was generally in favor of the concept. (A meeting summary is provided in Appendix C.) This working group would then make a recommendation and post it for 60 days, then take it to the Compliance Monitoring and Operating Practices Subcommittee (CMOPS) for the rule change

- ORNL will make a presentation to the CAISO on the concept and request that the rule change be considered as part of the market redesign. In addition, we will establish the needed frequency response criteria, i.e., the frequency droop setpoint and response time.

- At this point, the procedural path would be made clear for the CDWR to implement the change in the rule redesign if CDWR officials feel the specific revision would add a useful level of flexibility to its operations and would provide a potentially significant new revenue source.

- Within the context of its ongoing Future Operations Program, CDWR will consider modifying operational procedures, as well as incorporating needed software changes to its SCADA system to accommodate the new CAISO spinning reserve requirements. Further evaluation of soft starters (need, cost, physical and operational feasibility) would also be necessary prior to initiating a pilot program.

- Should CDWR proceed with a pilot program, ORNL would monitor the program and prepare a final report. 



\section{REFERENCES}

CAISO (California Independent System Operator) 2000, FERC Electric Tariff, First Replacement Volume No. I, California Independent System Operator Corporation, October 13.

CAISO (California Independent System Operator) 2003a, http://oasis.caiso.com/

CAISO (California Independent System Operator) 2003b, www.caiso.com

CAISO (California Independent System Operator) 2003c, “Actual Operating Reserves:

Frequently Asked Questions,” http://www1.caiso.com/docs/09003a6080/17/04/

09003a60801704db.pdf)

Hoffman 2003, personal communication between Brendan Kirby, ORNL, and Kyle Hoffman, CAISO Market Services.

NERC (North American Electric Reliability Council) 2002, NERC Operating Manual, Princeton, New Jersey, November 21.

FERC (U.S. Federal Energy Regulatory Commission) 2002a, Notice of Proposed Rulemaking: Remedying Undue Discrimination through Open Access Transmission Service and Standard Electricity Market Design, Docket No. RM01-12-000, Washington, D.C., July 31.

WECC (Western Electricity Coordinating Council) 2002, Reliability Criteria, Part III-Minimum Operating Reliability Criteria, Salt Lake City, Utah, August. 

APPENDIX A

SIEMENS TECHNICAL CONCEPT AND BUDGETARY ESTIMATE FOR PUMP MOTOR STARTING FREQUENCY CONVERTER 




\section{APPENDIX B SPINNING AND NON-SPINNING REVENUE PER PUMP}

Table B.1 presents modeling results for each individual pump supplying spinning reserves. Results are sorted by total annual revenue in the left three columns and by revenue per megawatt of pumping capacity in the right three columns. There is a $\$ 1 / \mathrm{MWh}$ minimum price below which the pump does not provide reserve.

Table B.1. Individual pump annual spinning reserve revenue

\begin{tabular}{|c|c|c|c|c|c|c|}
\hline \multirow[b]{2}{*}{ Rank } & \multicolumn{3}{|c|}{ Total revenue } & \multicolumn{3}{|c|}{ Revenue/MW-pump-capacity } \\
\hline & $\begin{array}{l}\text { Pumping } \\
\text { station }\end{array}$ & $\begin{array}{l}\text { Pump } \\
\text { number }\end{array}$ & $\begin{array}{l}\text { Revenue } \\
\$ / \text { year }\end{array}$ & $\begin{array}{c}\text { Pumping } \\
\text { station }\end{array}$ & $\begin{array}{c}\text { Pump } \\
\text { number }\end{array}$ & $\begin{array}{l}\text { Revenue } \\
\text { \$/MW/year }\end{array}$ \\
\hline 1 & ED & 1 & $1,077,986$ & SB & 1 & 29,620 \\
\hline 2 & ED & 2 & 941,749 & SB & 2 & 29,572 \\
\hline 3 & ED & 3 & 885,733 & SB & 3 & 28,354 \\
\hline 4 & ED & 4 & 778,787 & $\mathrm{PO}$ & 1 & 28,163 \\
\hline 5 & DA & 1 & 656,991 & $\mathrm{DE}$ & 1 & 28,101 \\
\hline 6 & ED & 5 & 631,161 & $\mathrm{BL}$ & 1 & 27,928 \\
\hline 7 & BA & 3 & 490,387 & BS & 1 & 27,807 \\
\hline 8 & ED & 6 & 485,937 & CR & 1 & 27,716 \\
\hline 9 & ED & 7 & 419,431 & $\mathrm{BH}$ & 1 & 27,542 \\
\hline 10 & BA & 4 & 418,137 & $\mathrm{CR}$ & 2 & 26,385 \\
\hline 11 & BA & 5 & 352,082 & $\mathrm{BS}$ & 2 & 26,061 \\
\hline 12 & ED & 8 & 335,661 & $\mathrm{BH}$ & 2 & 25,703 \\
\hline 13 & $\mathrm{BA}$ & 6 & 292,668 & SB & 4 & 24,129 \\
\hline 14 & DA & 2 & 286,134 & $\mathrm{BA}$ & 1 & 23,333 \\
\hline 15 & ED & 9 & 269,792 & $\mathrm{BH}$ & 3 & 22,966 \\
\hline 16 & WG & 1 & 241,352 & VJ & 1 & 22,497 \\
\hline 17 & $\mathrm{BA}$ & 7 & 240,550 & $\mathrm{BA}$ & 2 & 22,336 \\
\hline 18 & WG & 2 & 216,768 & BS & 3 & 21,110 \\
\hline 19 & BA & 1 & 205,910 & DA & 1 & 20,988 \\
\hline 20 & BA & 2 & 197,111 & SB & 5 & 20,255 \\
\hline 21 & ED & 10 & 195,656 & $\mathrm{BH}$ & 4 & 20,117 \\
\hline 22 & WG & 4 & 160,089 & $\mathrm{BA}$ & 3 & 18,180 \\
\hline 23 & ED & 11 & 136,623 & BL & 2 & 17,463 \\
\hline 24 & WG & 3 & 126,844 & $\mathrm{DE}$ & 2 & 17,398 \\
\hline 25 & WR & 1 & 114,639 & $\mathrm{PO}$ & 2 & 17,343 \\
\hline 26 & $\mathrm{~PB}$ & 1 & 113,647 & ED & 1 & 17,341 \\
\hline 27 & $\mathrm{BV}$ & 1 & 113,411 & $\mathrm{BV}$ & 1 & 17,028 \\
\hline 28 & PB & 3 & 105,805 & CR & 3 & 16,396 \\
\hline 29 & $\mathrm{BV}$ & 2 & 103,883 & SB & 6 & 16,334 \\
\hline 30 & WR & 2 & 102,506 & $\mathrm{BV}$ & 2 & 15,597 \\
\hline 31 & ED & 12 & 98,486 & $\mathrm{BA}$ & 4 & 15,501 \\
\hline 32 & $\mathrm{BA}$ & 8 & 92,792 & ED & 2 & 15,150 \\
\hline 33 & PB & 2 & 92,228 & $\mathrm{BS}$ & 4 & 14,975 \\
\hline 34 & DA & 3 & 80,580 & $\mathrm{BH}$ & 5 & 14,972 \\
\hline 35 & $\mathrm{BV}$ & 4 & 68,557 & WR & 1 & 14,753 \\
\hline 36 & SB & 5 & 62,956 & ED & 3 & 14,249 \\
\hline 37 & WR & 4 & 62,684 & WG & 1 & 14,027 \\
\hline 38 & $\mathrm{SB}$ & 2 & 57,446 & WR & 2 & 13,192 \\
\hline
\end{tabular}




\begin{tabular}{|c|c|c|c|c|c|c|}
\hline \multirow[b]{2}{*}{ Rank } & \multicolumn{3}{|c|}{ Total revenue } & \multicolumn{3}{|c|}{ Revenue/MW-pump-capacity } \\
\hline & $\begin{array}{c}\text { Pumping } \\
\text { station }\end{array}$ & $\begin{array}{c}\text { Pump } \\
\text { number }\end{array}$ & $\begin{array}{c}\text { Revenue } \\
\$ / \text { year }\end{array}$ & $\begin{array}{c}\text { Pumping } \\
\text { station }\end{array}$ & $\begin{array}{c}\text { Pump } \\
\text { number }\end{array}$ & $\begin{array}{l}\text { Revenue } \\
\text { \$/MW/year }\end{array}$ \\
\hline 39 & BV & 3 & 55,998 & $\mathrm{BA}$ & 5 & 13,053 \\
\hline 40 & SB & 3 & 55,081 & OS & 1 & 13,011 \\
\hline 41 & ED & 13 & 55,014 & SB & 7 & 12,623 \\
\hline 42 & WR & 3 & 52,158 & WG & 2 & 12,599 \\
\hline 43 & SB & 6 & 50,768 & ED & 4 & 12,528 \\
\hline 44 & OS & 5 & 48,873 & PB & 1 & 12,485 \\
\hline 45 & OS & 1 & 47,662 & $\mathrm{VJ}$ & 2 & 11,702 \\
\hline 46 & SB & 4 & 46,873 & BA & 6 & 10,850 \\
\hline 47 & SB & 7 & 39,233 & OS & 2 & 10,584 \\
\hline 48 & $\mathrm{PO}$ & 1 & 39,078 & ED & 5 & 10,153 \\
\hline 49 & $\mathrm{DE}$ & 1 & 38,992 & PB & 2 & 10,132 \\
\hline 50 & OS & 2 & 38,769 & OS & 3 & 9,259 \\
\hline 51 & $\mathrm{BL}$ & 1 & 38,751 & DA & 2 & 9,141 \\
\hline 52 & WG & 5 & 37,075 & $\mathrm{BA}$ & 7 & 8,918 \\
\hline 53 & $\mathrm{BH}$ & 5 & 35,151 & BV & 3 & 8,408 \\
\hline 54 & $\mathrm{BA}$ & 9 & 34,752 & OS & 4 & 8,021 \\
\hline 55 & OS & 3 & 33,916 & ED & 6 & 7,817 \\
\hline 56 & SB & 1 & 29,591 & WG & 3 & 7,372 \\
\hline 57 & OS & 4 & 29,384 & ED & 7 & 6,747 \\
\hline 58 & BL & 2 & 24,231 & WR & 3 & 6,712 \\
\hline 59 & $\mathrm{DE}$ & 2 & 24,140 & SB & 8 & 6,124 \\
\hline 60 & $\mathrm{PO}$ & 2 & 24,065 & PB & 3 & 6,014 \\
\hline 61 & $\mathrm{BH}$ & 1 & 21,401 & BS & 5 & 5,612 \\
\hline 62 & $\mathrm{BH}$ & 2 & 19,972 & ED & 8 & 5,400 \\
\hline 63 & $\mathrm{BV}$ & 5 & 18,929 & $\mathrm{BV}$ & 4 & 5,147 \\
\hline 64 & $\mathrm{BH}$ & 3 & 17,845 & $\mathrm{CR}$ & 4 & 5,145 \\
\hline 65 & PB & 4 & 17,490 & WG & 4 & 4652 \\
\hline 66 & SB & 8 & 16,655 & ED & 9 & 4340 \\
\hline 67 & WR & 5 & 15,532 & WR & 4 & 4034 \\
\hline 68 & ED & 14 & 13,453 & $\mathrm{BH}$ & 6 & 3802 \\
\hline 69 & $\mathrm{BH}$ & 4 & 12,282 & BA & 8 & 3440 \\
\hline 70 & OS & 6 & 12,229 & DV & 1 & 3392 \\
\hline 71 & BA & 10 & 12,222 & OS & 5 & 3335 \\
\hline 72 & CR & 2 & 11,422 & ED & 10 & 3147 \\
\hline 73 & $\mathrm{CR}$ & 1 & 10,768 & DA & 3 & 2574 \\
\hline 74 & BS & 3 & 9,725 & VJ & 3 & 2210 \\
\hline 75 & $\mathrm{BH}$ & 6 & 8,926 & ED & 11 & 2198 \\
\hline 76 & $\mathrm{CR}$ & 3 & 7,098 & ED & 12 & 1584 \\
\hline 77 & BS & 4 & 6,982 & BL & 3 & 1482 \\
\hline 78 & BS & 1 & 6,482 & BV & 5 & 1421 \\
\hline 79 & BS & 2 & 6,075 & BS & 6 & 1415 \\
\hline 80 & VJ & 1 & 3,122 & PO & 3 & 1393 \\
\hline 81 & BS & 5 & 2,616 & BA & 9 & 1288 \\
\hline 82 & OS & 7 & 2,389 & DV & 2 & 1166 \\
\hline 83 & CR & 4 & 2,227 & $\mathrm{CR}$ & 5 & 1160 \\
\hline 84 & BV & 6 & 2,195 & WG & 5 & 1077 \\
\hline 85 & BL & 3 & 2,057 & $\mathrm{DE}$ & 3 & 1055 \\
\hline 86 & $\mathrm{PO}$ & 3 & 1,933 & WR & 5 & 999 \\
\hline
\end{tabular}




\begin{tabular}{|c|c|c|c|c|c|c|}
\hline \multirow[b]{2}{*}{ Rank } & \multicolumn{3}{|c|}{ Total revenue } & \multicolumn{3}{|c|}{ Revenue/MW-pump-capacity } \\
\hline & $\begin{array}{c}\text { Pumping } \\
\text { station }\end{array}$ & $\begin{array}{c}\text { Pump } \\
\text { number }\end{array}$ & $\begin{array}{c}\text { Revenue } \\
\text { \$/year }\end{array}$ & $\begin{array}{c}\text { Pumping } \\
\text { station }\end{array}$ & $\begin{array}{c}\text { Pump } \\
\text { number }\end{array}$ & $\begin{array}{l}\text { Revenue } \\
\text { \$/MW/year }\end{array}$ \\
\hline 87 & $\mathrm{VJ}$ & 2 & 1,624 & $\mathrm{~PB}$ & 4 & 994 \\
\hline 88 & $\mathrm{DE}$ & 3 & 1,464 & ED & 13 & 885 \\
\hline 89 & SB & 9 & 1,350 & OS & 6 & 835 \\
\hline 90 & WR & 6 & 1,156 & BS & 7 & 576 \\
\hline 91 & WG & 6 & 1,125 & SB & 9 & 496 \\
\hline 92 & $\mathrm{CR}$ & 5 & 708 & BA & 10 & 453 \\
\hline 93 & MJ & 1 & 672 & DV & 3 & 280 \\
\hline 94 & BS & 6 & 660 & ED & 14 & 216 \\
\hline 95 & DV & 1 & 659 & BV & 6 & 165 \\
\hline 96 & BA & 11 & 656 & OS & 7 & 163 \\
\hline 97 & VJ & 3 & 601 & WR & 6 & 74 \\
\hline 98 & $\mathrm{BS}$ & 7 & 269 & $\mathrm{PO}$ & 4 & 65 \\
\hline 99 & DV & 2 & 226 & $\mathrm{BL}$ & 4 & 65 \\
\hline 100 & DA & 4 & 190 & $\mathrm{BL}$ & 5 & 60 \\
\hline 101 & PB & 5 & 177 & $\mathrm{DE}$ & 4 & 59 \\
\hline 102 & DA & 5 & 156 & $\mathrm{PO}$ & 5 & 59 \\
\hline 103 & PO & 4 & 90 & $\mathrm{BL}$ & 6 & 59 \\
\hline 104 & BL & 4 & 90 & $\mathrm{DE}$ & 5 & 59 \\
\hline 105 & BL & 5 & 83 & $\mathrm{DE}$ & 6 & 58 \\
\hline 106 & $\mathrm{DE}$ & 4 & 82 & $\mathrm{PO}$ & 6 & 54 \\
\hline 107 & PO & 5 & 82 & $\mathrm{CR}$ & 6 & 52 \\
\hline 108 & BL & 6 & 82 & WG & 6 & 33 \\
\hline 109 & $\mathrm{DE}$ & 5 & 82 & BA & 11 & 24 \\
\hline 110 & $\mathrm{DE}$ & 6 & 81 & BS & 8 & 17 \\
\hline 111 & $\mathrm{PO}$ & 6 & 75 & PB & 5 & 10 \\
\hline 112 & DV & 3 & 54 & DA & 4 & 6 \\
\hline 113 & DA & 6 & 50 & BS & 9 & 5 \\
\hline 114 & $\mathrm{CR}$ & 6 & 32 & DA & 5 & 5 \\
\hline 115 & BV & 8 & 15 & DA & 6 & 2 \\
\hline 116 & $\mathrm{BV}$ & 7 & 15 & VJ & 4 & 1 \\
\hline 117 & $\mathrm{BS}$ & 8 & 8 & BV & 8 & 1 \\
\hline 118 & BV & 9 & 3 & BV & 7 & 1 \\
\hline 119 & BS & 9 & 2 & $\mathrm{CR}$ & 7 & 0 \\
\hline 120 & WG & 7 & 1 & BV & 9 & 0 \\
\hline
\end{tabular}

Table B.2 presents modeling results for each individual pump supplying non-spinning reserves. Results are sorted by total annual revenue in the left three columns and by revenue per megawatt of pumping capacity in the right three columns. There is a minimum $\$ 1 / \mathrm{MWh}$ price below which the pump does not provide reserves.

Table B.2. Individual pump annual non-spinning reserve revenue

\begin{tabular}{ccccccc}
\hline \multirow{2}{*}{ Rank } & \multicolumn{3}{c}{ Total revenue } & \multicolumn{3}{c}{ Revenue/MW-pump-capacity } \\
\cline { 2 - 7 } & $\begin{array}{c}\text { Pumping } \\
\text { station }\end{array}$ & $\begin{array}{c}\text { Pump } \\
\text { number }\end{array}$ & \$/year & $\begin{array}{c}\text { Pumping } \\
\text { station }\end{array}$ & $\begin{array}{c}\text { Pump } \\
\text { number }\end{array}$ & \$/MW/year \\
\hline 1 & ED & 1 & 443,084 & SB & 1 & 13,722 \\
2 & ED & 2 & 356,037 & SB & 2 & 13,713
\end{tabular}




\begin{tabular}{|c|c|c|c|c|c|c|}
\hline \multirow[b]{2}{*}{ Rank } & \multicolumn{3}{|c|}{ Total revenue } & \multicolumn{3}{|c|}{ Revenue/MW-pump-capacity } \\
\hline & $\begin{array}{l}\text { Pumping } \\
\text { station }\end{array}$ & $\begin{array}{l}\text { Pump } \\
\text { number }\end{array}$ & $\$ /$ year & $\begin{array}{l}\text { Pumping } \\
\text { station }\end{array}$ & $\begin{array}{c}\text { Pump } \\
\text { number }\end{array}$ & $\$ / \mathrm{MW} /$ year \\
\hline 3 & ED & 3 & 328,684 & $\mathrm{PO}$ & 1 & 13,343 \\
\hline 4 & DA & 1 & 327,147 & SB & 3 & 13,341 \\
\hline 5 & ED & 4 & 279,485 & $\mathrm{DE}$ & 1 & 13,323 \\
\hline 6 & BA & 3 & 239,965 & BS & 1 & 13,259 \\
\hline 7 & BA & 4 & 212,549 & BL & 1 & 13,235 \\
\hline 8 & ED & 5 & 211,920 & $\mathrm{CR}$ & 1 & 13,229 \\
\hline 9 & BA & 5 & 182,814 & $\mathrm{BH}$ & 1 & 13,028 \\
\hline 10 & DA & 2 & 178,313 & $\mathrm{CR}$ & 2 & 12,796 \\
\hline 11 & ED & 6 & 157,104 & $\mathrm{BS}$ & 2 & 12,696 \\
\hline 12 & $\mathrm{BA}$ & 6 & 145,793 & $\mathrm{BH}$ & 2 & 12,259 \\
\hline 13 & BA & 7 & 119,960 & SB & 4 & 12,224 \\
\hline 14 & ED & 7 & 119,611 & VJ & 1 & 11,419 \\
\hline 15 & $\mathrm{BA}$ & 1 & 100,540 & BA & 1 & 11,393 \\
\hline 16 & $\mathrm{BA}$ & 2 & 98,181 & $\mathrm{BH}$ & 3 & 11,177 \\
\hline 17 & WG & 1 & 92,256 & BA & 2 & 11,125 \\
\hline 18 & ED & 8 & 82,704 & BS & 3 & 11,062 \\
\hline 19 & WG & 2 & 77,931 & SB & 5 & 10,895 \\
\hline 20 & ED & 9 & 67,781 & DA & 1 & 10,451 \\
\hline 21 & DA & 3 & 55,554 & $\mathrm{BH}$ & 4 & 10,302 \\
\hline 22 & $\mathrm{BV}$ & 1 & 48,338 & SB & 6 & 9,280 \\
\hline 23 & ED & 10 & 47,833 & BA & 3 & 8,896 \\
\hline 24 & $\mathrm{~PB}$ & 1 & 46,020 & $\mathrm{BS}$ & 4 & 8,702 \\
\hline 25 & WG & 4 & 44,451 & BL & 2 & 8,698 \\
\hline 26 & $\mathrm{BV}$ & 2 & 43,447 & $\mathrm{DE}$ & 2 & 8,646 \\
\hline 27 & WR & 1 & 43,393 & $\mathrm{PO}$ & 2 & 8,608 \\
\hline 28 & WG & 3 & 41,671 & $\mathrm{CR}$ & 3 & 8,385 \\
\hline 29 & WR & 2 & 37,497 & $\mathrm{BH}$ & 5 & 8,353 \\
\hline 30 & $\mathrm{BA}$ & 8 & 37,232 & BA & 4 & 7,880 \\
\hline 31 & PB & 3 & 36,609 & SB & 7 & 7,304 \\
\hline 32 & PB & 2 & 35,568 & BV & 1 & 7,258 \\
\hline 33 & SB & 5 & 33,862 & ED & 1 & 7,128 \\
\hline 34 & SB & 6 & 28,843 & BA & 5 & 6,777 \\
\hline 35 & ED & 11 & 28,520 & BV & 2 & 6,523 \\
\hline 36 & SB & 2 & 26,638 & VJ & 2 & 6,459 \\
\hline 37 & SB & 3 & 25,917 & ED & 2 & 5,727 \\
\hline 38 & SB & 4 & 23,747 & DA & 2 & 5,696 \\
\hline 39 & SB & 7 & 22,700 & WR & 1 & 5,584 \\
\hline 40 & ED & 12 & 20,731 & BA & 6 & 5,405 \\
\hline 41 & BV & 4 & 20,011 & WG & 1 & 5,362 \\
\hline 42 & $\mathrm{BH}$ & 5 & 19,611 & ED & 3 & 5,287 \\
\hline 43 & $\mathrm{PO}$ & 1 & 18,515 & PB & 1 & 5,056 \\
\hline 44 & DE & 1 & 18,487 & WR & 2 & 4,826 \\
\hline 45 & BL & 1 & 18,365 & OS & 1 & 4,719 \\
\hline 46 & BV & 3 & 18,217 & WG & 2 & 4,529 \\
\hline 47 & OS & 1 & 17,288 & ED & 4 & 4,496 \\
\hline 48 & WR & 4 & 16,115 & BA & 7 & 4,447 \\
\hline 49 & WR & 3 & 15,839 & PB & 2 & 3,908 \\
\hline 50 & $\mathrm{SB}$ & 1 & 13,709 & OS & 2 & 3,647 \\
\hline
\end{tabular}




\begin{tabular}{|c|c|c|c|c|c|c|}
\hline \multirow[b]{2}{*}{ Rank } & \multicolumn{3}{|c|}{ Total revenue } & \multicolumn{3}{|c|}{ Revenue/MW-pump-capacity } \\
\hline & $\begin{array}{l}\text { Pumping } \\
\text { station }\end{array}$ & $\begin{array}{l}\text { Pump } \\
\text { number }\end{array}$ & \$/year & $\begin{array}{c}\text { Pumping } \\
\text { station }\end{array}$ & $\begin{array}{l}\text { Pump } \\
\text { number }\end{array}$ & $\$ / \mathrm{MW} /$ year \\
\hline 51 & OS & 2 & 13,360 & BS & 5 & 3,591 \\
\hline 52 & OS & 5 & 12,545 & SB & 8 & 3,511 \\
\hline 53 & BL & 2 & 12,069 & ED & 5 & 3,409 \\
\hline 54 & $\mathrm{DE}$ & 2 & 11,997 & OS & 3 & 3,070 \\
\hline 55 & PO & 2 & 11,944 & CR & 4 & 2,881 \\
\hline 56 & OS & 3 & 11,244 & BV & 3 & 2,735 \\
\hline 57 & $\mathrm{BH}$ & 1 & 10,123 & OS & 4 & 2,532 \\
\hline 58 & SB & 8 & 9,548 & ED & 6 & 2,527 \\
\hline 59 & $\mathrm{BH}$ & 2 & 9,526 & WG & 3 & 2,422 \\
\hline 60 & OS & 4 & 9,275 & $\mathrm{BH}$ & 6 & 2,084 \\
\hline 61 & BA & 9 & 9021 & PB & 3 & 2,081 \\
\hline 62 & ED & 13 & 8967 & WR & 3 & 2,038 \\
\hline 63 & $\mathrm{BH}$ & 3 & 8685 & ED & 7 & 1,924 \\
\hline 64 & WG & 5 & 8451 & DA & 3 & 1,775 \\
\hline 65 & $\mathrm{BH}$ & 4 & 6290 & DV & 1 & 1563 \\
\hline 66 & $\mathrm{CR}$ & 2 & 5540 & BV & 4 & 1502 \\
\hline 67 & CR & 1 & 5140 & BA & 8 & 1380 \\
\hline 68 & BS & 3 & 5096 & ED & 8 & 1330 \\
\hline 69 & $\mathrm{BH}$ & 6 & 4893 & WG & 4 & 1292 \\
\hline 70 & PB & 4 & 4870 & VJ & 3 & 1232 \\
\hline 71 & BV & 5 & 4328 & ED & 9 & 1090 \\
\hline 72 & BS & 4 & 4057 & WR & 4 & 1037 \\
\hline 73 & CR & 3 & 3630 & BS & 6 & 998 \\
\hline 74 & BS & 1 & 3091 & OS & 5 & 856 \\
\hline 75 & BS & 2 & 2960 & ED & 10 & 769 \\
\hline 76 & BA & 10 & 2880 & $\mathrm{CR}$ & 5 & 702 \\
\hline 77 & OS & 6 & 2537 & BL & 3 & 607 \\
\hline 78 & WR & 5 & 2415 & PO & 3 & 537 \\
\hline 79 & BS & 5 & 1674 & ED & 11 & 459 \\
\hline 80 & VJ & 1 & 1584 & DV & 2 & 454 \\
\hline 81 & ED & 14 & 1412 & $\mathrm{DE}$ & 3 & 392 \\
\hline 82 & CR & 4 & 1247 & SB & 9 & 345 \\
\hline 83 & SB & 9 & 937 & BA & 9 & 334 \\
\hline 84 & VJ & 2 & 896 & ED & 12 & 333 \\
\hline 85 & BL & 3 & 843 & BV & 5 & 325 \\
\hline 86 & PO & 3 & 746 & BS & 7 & 323 \\
\hline 87 & $\mathrm{PF}$ & 1 & 620 & PB & 4 & 277 \\
\hline 88 & $\mathrm{DE}$ & 3 & 544 & WG & 5 & 246 \\
\hline 89 & BS & 6 & 465 & OS & 6 & 173 \\
\hline 90 & BV & 6 & 432 & WR & 5 & 155 \\
\hline 91 & CR & 5 & 428 & ED & 13 & 144 \\
\hline 92 & VJ & 3 & 335 & BA & 10 & 107 \\
\hline 93 & WG & 6 & 330 & DV & 3 & 93 \\
\hline 94 & DV & 1 & 304 & CR & 6 & 38 \\
\hline 95 & OS & 7 & 264 & BV & 6 & 32 \\
\hline 96 & BA & 11 & 175 & BL & 4 & 31 \\
\hline 97 & BS & 7 & 151 & PO & 4 & 24 \\
\hline 98 & DV & 2 & 88 & $\mathrm{DE}$ & 4 & 23 \\
\hline
\end{tabular}




\begin{tabular}{ccccccc}
\hline \multirow{2}{*}{ Rank } & \multicolumn{3}{c}{ Total revenue } & \multicolumn{3}{c}{ Revenue/MW-pump-capacity } \\
\cline { 2 - 6 } & $\begin{array}{c}\text { Pumping } \\
\text { station }\end{array}$ & $\begin{array}{c}\text { Pump } \\
\text { number }\end{array}$ & \$/year & $\begin{array}{c}\text { Pumping } \\
\text { station }\end{array}$ & $\begin{array}{c}\text { Pump } \\
\text { number }\end{array}$ & \$/MW/year \\
\hline 99 & BL & 4 & 43 & ED & 14 & 23 \\
100 & PO & 4 & 34 & BL & 5 & 20 \\
101 & DE & 4 & 32 & PO & 5 & 19 \\
102 & BL & 5 & 27 & BL & 6 & 19 \\
103 & PO & 5 & 27 & DE & 5 & 19 \\
104 & BL & 6 & 27 & DE & 6 & 19 \\
105 & DE & 5 & 27 & OS & 7 & 18 \\
106 & DE & 6 & 26 & PO & 6 & 18 \\
107 & PO & 6 & 25 & WG & 6 & 10 \\
108 & CR & 6 & 23 & BA & 11 & 6 \\
109 & DV & 3 & 18 & BS & 8 & 2 \\
110 & PB & 5 & 18 & PB & 5 & 1 \\
111 & WR & 6 & 11 & WR & 6 & 1 \\
\hline
\end{tabular}




\title{
APPENDIX C
}

\section{NOTES FROM WECC MORC WORKING GROUP MEETING OF NOVEMBER 6, 2003}

\author{
WECC MORC (Minimum Operating Reliability Criteria) Working Group
}

Brendan Kirby and John Kueck made a presentation on allowing spinning reserve to be provided from load to the MORC WG on Nov. 6, 2003. The presentation was well received. After the presentation, there was nearly an hour of questions and answers. Several members stated that they thought the concept was a good idea, but there were several issues that needed to be addressed, as follows:

- How would the quantity of dispatched spin be controlled? Could it be controlled only by the market? We responded that the California ISO dispatches spin by going down the bid stack and dispatching as much as needed. Spin from load could be done the same way.

- Would the financial incentive be there for small loads to install the needed equipment, for example, a frequency chip? Response: This would be a function of the market. If there is money to be made, the equipment could be justified. The hardware costs would also be expected to come down when there is a dependable market. Alternatively, regulators could require that the capability be installed if the cost is as low as expected. There are several regulatory \&/or market solutions that could be used.

- For the extremely large loads, for example, the CDWR pumps, if you trip three large pumps, and then the lost generation is restored, and it takes a while to get the pumps restarted, you may have a load - generation mismatch. You may also wind up tripping more pumps during light load conditions because the initial frequency decay after a contingency may go lower. Response: This could probably be handled by the timing of the pump trips and the generator droop characteristics. You could also ramp back other generation if the inherent controls do not correct back to zero.

- How do you write the reliability regulations to do all this? Response: It may be appropriate to do some testing first, get the needed data, then write the rules. SCE has indicated that they would be interested in testing the Comfort Choice thermostats for spinning reserve.

- Definitions can sometimes be quite challenging. The working group has been trying for four years to define "firm". The regulations they need to go along with the spin from load change will not be simple. The chairman said that before they open the door, they had to have the rules in place. There would be details of getting paid for availability and energy, does generation or load take priority, could a load participate in demand response and spin? Response: We understand. Mr. Kirby provided details and presentation of spin from load is done in Ireland.

- They have historically been skeptical of statistical response accuracy. Response: The mathematical fact is that a statistical response from a large number of small sources is more consistent than the response from a few 
large sources. Also, you can test the small sources, you can send out a signal saying do nothing and respond back.

- They may have to separate spin from replacement reserves. There was some discussion on definitions. There are different definitions for some of the services for different control areas within WECC. For example, WAPA does not have replacement reserves, they use additional spin. Restoring reserves take a lot of forms, supply from neighbors, etc. Response: The rules would have to be prepared on a functional basis.

- The spread sheet that we used to find the number of frequency excursions was titled WECC Frequency Disturbances. We were told that this spread sheet only covered disturbances caused by loss of generation, and that the total number of frequency excursions was higher, especially the small ones down to $59.965 \mathrm{~Hz}$.

- We asked if they could outline the tests that they would need to build the required confidence and characterize the potential resource. Perhaps we could work with SCE and others to have them performed.

The working group concluded that they were generally in favor of the concept. They are going to discuss the needs from the WECC rulemaking perspective. Our next step would probably be to make a presentation to the Performance Work Group. This work group would then make a recommendation and post it for 60 days, then take it to the Compliance Monitoring and Operating Practices Subcommittee (CMOPS). They said they would get back to us with our next steps. 